\title{
On the rumors about the silent spring. Review of the scientific evidence linking occupational and environmental pesticide exposure to endocrine disruption health effects
}

\author{
Rumores de uma primavera silenciosa: \\ uma revisão das evidências científicas sobre \\ a associação entre exposição ocupacional \\ e ambiental a pesticidas e distúrbios endócrinos
}

1 Sezione di Medicina del Lavoro, Dipartimento di Igiene e Sanitá Publica, Facoltà di Medicina e Chirurgia, Università degli Studi di Cagliari. Via San Giorgio 12 09124 Cagliari, Italia. coccop@pacs.unica.it

\begin{abstract}
Occupational exposure to some pesticides, and particularly DBCP and chlordecone, may adversely affect male fertility. However, apart from the therapeutic use of diethylstilbestrol, the threat to human reproduction posed by "endocrine disrupting" environmental contaminants has not been supported by epidemiological evidence thus far. As it concerns other endocrine effects described in experimental animals, only thyroid inhibition following occupational exposure to amitrole and mancozeb has been confirmed in humans. Cancer of the breast, endometrium, ovary, prostate, testis, and thyroid are hormone-dependent, which fostered research on the potential risk associated with occupational and environmental exposure to the so-called endocrine-disrupting pesticides. The most recent studies have ruled out the hypothesis of DDT derivatives as responsible for excess risks of cancer of the reproductive organs. Still, we cannot exclude a role for high level exposure to o, $p^{\prime}-D D E$, particularly in post-menopausal ER+breast cancer. On the other hand, other organochlorine pesticides and triazine herbicides require further investigation for a possible etiologic role in some hormone-dependent cancers.
\end{abstract}

Key words Reproduction; Antithyroid Agents; Neoplasms; Pesticides; Endocrine Disruptors

Resumo A exposição ocupacional a determinados pesticidas, particularmente ao DBCP e à clordecona, pode ter efeitos adversos sobre a fertilidade masculina. Entretanto, com exceção do uso terapêutico do dietil-estilbestrol, a ameaça à reprodução humana através da "desregulação endócrina" por contaminantes ambientais ainda não foi comprovada através de evidências epidemiológicas. A questão diz respeito a outros efeitos endócrinos descritos em animais experimentais, e apenas a inibição tireóide foi confirmada em seres humanos, após exposição ocupacional a amitrole e mancozeb. O fato de serem hormônio-dependentes os cânceres de mama, endométrio, ovário, próstata, testículos e tireóide motivou pesquisas sobre o risco potencial associado à exposição ocupacional e ambiental aos pesticidas conhecidos como "desreguladores endócrinos". Os estudos mais recentes descartaram a hipótese dos derivados do DDT como responsáveis pelo risco em excesso de câncer dos órgãos reprodutivos. Entretanto, não se pode excluir o papel da exposição elevada ao o, p'-DDE, particularmente no câncer de mama pós-menopáusica, positivo para receptores estrogênicos. Além disso, há necessidade de mais investigação sobre o possível papel etiológico de outros pesticidas organoclorados e herbicidas triazínicos em alguns cânceres hormônio-dependentes.

Palavras-chave Reprodução; Antitiroidianos; Neoplasias; Praguicidas; Desreguladores Endócrinos 


\section{Endocrine system and pesticides}

\section{Experimental studies}

Reproductive effects of pesticides have received special attention among the investigators. The discovery that organochlorines, such as hexachlorocyclohexane $(\mathrm{HCH}) \gamma$ - and $\delta$-isomers, dichlorodiphenyl-trichloroethane (DDT) isomers $p, p^{\prime}$-DDT and $o, p^{\prime}$-DDT, its $p, p^{\prime}$-DDE derivative, methoxychlor (or dianisyl-trichloroethane, a structural analogue of DDT), dieldrin, and pentachlorophenol, as well as atrazine, a widely used nitrogen herbicide, bind in vitro to the rat androgen receptor, significantly inhibiting the specific binding of $[3 \mathrm{H}] 5 \alpha$-dihydroxytestosterone (DHT) (Kelce et al., 1995), further fostered research on the issue. Such an anti-androgen effect was mostly prominent for $p, p^{\prime}$-DDE (Fent, 1997; Kelce et al., 1995). Besides, the $o, p^{\prime}$-DDT levo enantiomer (Chen et al., 1997; Dees et al., 1997; Fent, 1997; McBlain \& Lewin, 1976), nonylphenol, and to a lesser extent also methoxychlor and pentachlorophenol, but not $\beta-\mathrm{HCH}$ (Steinmetz et al., 1996), link to the rat estrogen receptor significantly reducing in vitro $[3 \mathrm{H}] 17 \beta$-estradiol binding (Danzo, 1997). Also, alachlor, trans-nonachlor, endosulfan, and atrazine competed with $[3 \mathrm{H}]$ $17 \beta$-estradiol for binding to the alligator estrogen receptor (ER), while endosulfan, alachlor, and kepone (also known as chlordecone) inhibited the binding of the synthetic progestin [3H]R5020 to alligator pregesterone receptor (aPR) (Vonier et al., 1996). The $\gamma$ isomer of $\mathrm{HCH}$, on the other hand, did not have an effect on the binding of radiolabelled estradiol to the uterine endometrial explants in bovine, as derived from the effects on DNA synthesis. The uterine response to $o, p^{\prime}$-DDT administration in immature rats is similar to that elicited by $17 \beta$ estradiol, with an increase in DNA synthesis and cell division in the luminal epithelium, stroma and myometrium (Robison et al., 1985). However, the maximum response following $o, p$-DDT treatment varies by cell type, from $70 \%$ of that produced by $17 \beta$-estradiol in stroma and myometrium, to the same though delayed maximum response in the luminal epithelium (Robison et al., 1985). Consistently, $o, p^{\prime}$-DDT and methoxychlor produce the uterine hyperplasia characteristic of estrogens, although with the magnitude and timing of the response is dependent on the specific cell type observed, the concentration, and the animal species (Tiemann et al., 1996; Ulrich et al., 2000 ), and mice treated with $o, p^{\prime}$-DDT and $\beta$ $\mathrm{HCH}$, at blood concentrations equal to or above
$18 \mathrm{ng} / \mathrm{ml}$ and $42 \mathrm{ng} / \mathrm{ml}$ respectively, showed increased uterine epithelial height and vaginal epithelial thickness compared to control animals (Ulrich et al., 2000). Also, $o, p^{\prime}$-DDT inhibits the binding of $3 \mathrm{H}$-estradiol to the 8-9S estrogen binding protein of rat testicular cytosol, while $p, p^{\prime}$-DDE does not, and methoxychlor requires metabolic activation (Bulger et al., 1978; Cummings, 1997). In fact, its didemethylated metabolite 2,2-bis(p-hydroxyphenyl)-1,1,1-trichloroethane (HPTE) causes marked suppression of $3 \mathrm{H}$-estradiol binding (Bulger et al., 1978; Cummings, 1997). When administered orally to pregnant mice from days 11-17 of pregnancy, $o, p^{\prime}$-DDT and methoxychlor reduced significantly the rate of urine marking by male offspring in adulthood at the highest dose administered prenatally (vom Saal et al., 1995). Relative binding to estrogen receptors in MCF-7 cells accurately predicted the doses of $o, p^{\prime}$-DDT and methoxychlor that produced the same results, providing support for the hypothesis that effects on behavior were mediated by binding to estrogen receptors in the developing brain (vom Saal et al., 1995). It has been reported that $o, p^{\prime}$-DDE could transactivate the human Estrogen Receptor (hER) in MCF-7 and T-47D human breast cancer cells with a 140 - to 300 -fold weaker potency than that of estradiol (Kupfer \& Bulger, 1977; McBlain, 1987), eliciting an additive response when given together with estradiol (McBlain, 1987). These concentrations were considered close or around the range of concentrations among exposed human populations. $O, p^{\prime}$-DDT induces an estrogen-inducible protein indistinguishable from that formed after $17 \beta$-estradiol, without additional induction over that seen with maximum levels of the natural estrogen, further supporting the premise that these compounds share a common pathway in stimulating the synthesis of induced protein (Robison et al., 1984). DDT isomers and metabolites may also stimulate other estrogenic endpoints in estrogen-responsive MCF-7 cells, such as the induction of the progesterone receptor, the inhibition of the progesterone-induced reporter gene activity in a dose-dependent manner through both hPR-dependent and hPR-independent pathways, and the down-regulation of the hER (Chen et al., 1997; Klotz et al., 1997b; Mason et al., 1980).

Estrogenic properties, as derived from the proliferative effect in the MCF7-E3 human breast cancer cell model, have been described also for Toxaphene (or polychlorocamphene) (Soto et al., 1994; Stelzer \& Chan, 1999), a mixture of over 800 congeners, largely used as an 
insecticide in the United States until 1982, primarily to control insect pests on cotton and other crops, on livestock and to kill unwanted fish in lakes. Other organochlorine pesticides, such as dieldrin, and endosulfan revealed estrogenic properties comparable to those of DDT and chlordecone in the MCF7-E3 model. In this assay, when mixed together, estrogenic chemicals may act cumulatively inducing estrogenic responses at concentrations lower than those required when each compound is administered alone (Soto et al., 1994). Other pesticides, such as the carbamate insecticides aldicarb, Baygon (propoxur), bendiocarb, carbaryl, methomyl, and oxamyl demonstrated a limited capacity to displace radiolabeled estrogen or progesterone from ER or PR in whole cell competition binding assays (Klotz et al., 1997a). Parathion, possibly the most widely used organo-phosphorous insecticide, interfered with normal differentiation of A/Snell mice testes, implanted in the allantochorion of chicken eggs treated with the pesticide, causing a complete disorganisation of the seminiferous cords and the testicular interstitium (Rojas et al., 1998).

Pesticides may interfere with sexual hormones also through indirect non receptorial mechanisms (Fent, 1997). For instance, $o, p^{\prime}-$ DDT stimulates rat uterine contraction in a fashion not dependent on Prostaglandin E2 release or direct estrogen receptor-related action (Juberg \& Loch-Caruso, 1992) and chlordecone is capable of inhibiting sexual behavior in rodents, but this effect does not depend on an attenuation of estradiol-dependent elevation of CNS progesterone receptors (Eckols et al., 1989). Nonylphenol, and to a lesser extent also HCH, o.p'-DDT and pentachlorophenol, reduce [3H] $5 \alpha$-DHT binding to the human sex hormone-binding globulin (hSHBG) (Danzo, 1997). Organo-tin compounds inhibit cytochrome P450 dependent monoxygenases, such as aromatase, which oxidizes testosterone to estradiol (Fent, 1997). In these two last instances, the resulting effect is an increase of the quote of serum free testosterone available to link the androgen receptor, i.e. a pro-androgen effect. Activation of liver microsomial enzymes by organochlorines such as $o, p^{\prime}$-DDT, $p, p^{\prime}$-DDE, Chlordecone and Mirex, causes a dose and time dependent increase in estrogen metabolism through 2-hydroxylation of estradiol (Britton, 1975; Bulger \& Kupfer, 1983). Treatment with DDT, and to a lesser extent methoxychlor, markedly induced the cytochromes P4502B1/ 2B2 and 3A activity, but not CYP2E1 or the P450 reductase activity, in treated rats (Li et al., 1995).
Therefore, the resulting increase in testosterone and methoxychlor hydroxylation was related to induction of certain P450 enzymes, and not to enhanced reductase activity. It has been subsequently shown that CYPs induction by DDT differs by gender, with a 18 -fold increase in CYP3A2 activity among female Wistar rats versus a non significant less than 3 -fold induction in males (Sierra-Santoyo et al., 2000). As CYP3A2 is androgen dependent, the authors inferred that DDT is capable of modulating sexual metabolic dimorphism. CYP2B1/2B2 activity also showed a 19-fold increase in both genders. However, as no correlation exists between the ability to induce hepatic microsomal estradiol-2-hydroxylase activity and estrogenic (or antiestrogenic) properties of a given compound (Britton, 1975; Bulger \& Kupfer, 1983), it is not clear whether and to what extent such in vivo indirect effects could add to or counterbalance the direct receptorial effects of hormone-like pesticides. Also, due to the multiple in vivo targets of the same pesticide often resulting in opposite end points, differences between in vitro and in vivo assays are to be expected. Further difficulties in extrapolating from experimental results to forecast human health effects arise from the dose of the toxicant administered to the experimental animal, which is several orders of magnitude greater than that resulting from occupational or environmental exposure, and from humans experiencing multiple exposures at the same time (such as with diet or drinking water) or close in time (such as in agricultural occupations). To match the peculiarities of human exposure to pesticides, real life mixtures of pesticides at concentrations similar to those found in contaminated groundwater in Iowa (alachlor, atrazine, cyanazine, metolachlor, metribuzin, and ammonium nitrate) and California (aldicarb, atrazine, dibromochloropropane, 1-2 dichloropropane, ethylene dibromide, simazine, and ammonium nitrate) were administered to Swiss CD-1 mice (Chapin \& Gulati, 1997; Heindel et al., 1997). No detectable reproductive effects were observed, although animals treated with the California pesticide mix showed on average a $11 \%$ reduction in seminal vesicle weight (Chapin \& Gulati, 1997).

\section{Epidemiological studies}

Comparison of occupations among couples seeking artificial insemination with donor sperm because of poor sperm quality versus couples treated by in-vitro fertilization due to female causes revealed a significantly greater 
prevalence of agricultural occupations among spouses with male factor infertility, who also reported more long-term exposure to numerous insecticides and other pesticides (Strohmer et al., 1993). Findings among Danish pesticide sprayers did not confirm a generalized risk in farming occupations, as their median sperm concentration was not statistically different from unexposed men, and there were not significant changes in the sperm morphology, vitality, motility, sperm chromatin denaturation, and reproductive hormones following pesticide exposure (Larsen et al., 1999). Other studies have evaluated fecundability, i.e. the ability to obtain conception within a menstrual cycle (Olsen, 1994), or the "time to pregnancy" (TTP) index, i.e. the time with unprotected intercourse before achieving pregnancy (Baird et al., 1986; Joffe, 1997), as the outcome in relation to pesticide exposure. Results were also contradictory. Spouses of Dutch fruit growers, mostly exposed to the fungicide captan, showed a significant reduction of the fecundability ratio, particularly when the couple had tried to start pregnancy in the period when pesticides were applied, and in coincidence with numerous indicators of high level pesticide exposure (De Cock et al., 1994). Spouses of Italian greenhouse workers had a significantly longer TTP (5.4 months, $s d 5.6$ ) compared to spouses of white collar workers (3.9 months, $s d 3.1$ ), and TTP was mostly prolonged among workers who did not use personal protective equipment and among those heaviest exposed (Petrelli et al., $2000 \mathrm{~b})$. On the other hand, no effect of pesticide exposure on male fertility, evaluated with the adjusted fecundability ratio in the spouse, was observed among Danish and French greenhouse workers, vineyard workers, and other agricultural workers (Thonneau et al., 1999a, 1999b). Also, a Canadian study did not find a consistent pattern of association of pesticide exposure with time to pregnancy (Curtis et al., 1999). Only during exposure intervals in which women participated in pesticide activities (although in most instances the men also participated), a decrease in fecundability was observed related to the herbicides dicamba, glyphosate, and 2,4-D, and to organophosphates, thiocarbamates, and carbaryl. The conditional fecundability ratio ranged 0.51-0.80, but none was statistically significant (Curtis et al., 1999). It is unclear whether an endocrine mechanism or an increase in the spontaneous abortion rate in the earliest period of pregnancy due to other factors, such as teratogenic effects of some pesticides, might account for the decrease in fecundability observed in some studies. However, although not relevant from a Public Health perspective, such a possibility is worth to be considered for the medical diagnosis of infertility, defined as a waiting time of 12 months or more before conception, which showed a 3-fold increase in risk among women exposed to pesticides (Smith et al., 1997). Also, male-mediated risk of spontaneous abortion showed a 3.8-fold increase and the ratio of spontaneous abortions/pregnancies was 0.27 among the wives of 51 Italian pesticide applicators, whose exposure list included fenthion, DDVP, chlordane, DDT, dieldrin, lindane, malathion, and trichlorfon, compared to the wives of 51 food retailers, as the referents (spontaneous abortions $/$ pregnancies ratio $=$ 0.07) (Petrelli et al., 2000a).

The epidemiological inquiry into the reproductive effects of individual chemicals in agricultural settings is particularly difficult, and results sometimes poorly interpretable, due to the extremely complex pattern of exposure, resulting from the yearly use of a large number of individual chemicals for the same crop, the frequent variety of crops raised in the same farm, and the change in type of crops and chemical treatments along the years. Nonetheless, dibromochloropropane (DBCP), mostly used as an insecticide in banana plantations, was identified as a significant reproductive hazard causing infertility and sterility in men (Whorton et al., 1979). Azoospermia and oligospermia was largely above expectation among workers in DBCP manufacturing plants, with evidence of a relationship between duration of employment and effect on testicular function. Also, a lower fertility level and sterility were reported among agricultural workers exposed to DBCP in Costa Rica banana plantations (Potashnik \& Porath, 1995). Plasma follicle-stimulating hormone (FSH) and luteinizing hormone ( $\mathrm{LH})$ were significantly increased and testosterone level was not significantly decreased among the DBCP severely affected individuals (Kharrazi et al., 1980). Since removal of DBCP exposure, recovery of fertility was reported among some men who showed improvements in sperm counts, while others remained either azoospermic or severely oligospermic (Whorton, 1994). Such an inter-individual variation in the response might be related to polymorphisms of metabolizing genes, such as cytochrome P4502E1, the glutathione S-transferases $\mathrm{m}$ and $\mathrm{q}$, and the paraoxonase genes (Au et al., 1999). Also, an Israeli study of DBCP exposed banana workers showed a threefold increase in spontaneous abortion (Kharrazi et al., 1980), while there was no increase in the 
rate of spontaneous abortions and congenital malformations among pregnancies conceived during or after DBCP exposure in a more recent study (Potashnik \& Porath, 1995). However, a low prevalence of male infants conceived during paternal exposure was found as compared with the pre-exposure period $(16.6 \%$ versus $52.9 \%$; $p<0.025$ ). Restoration of fertility was followed by a gradual increase of this value to $41.4 \%$ (Potashnik \& Porath, 1995). No adverse effect on sperm count was reported for DBCP exposure within the current OSHA standard (1 ppb) (Whorton, 1994).

Other individual pesticides have been less frequently evaluated in human studies. Kepone (chlordecone) has been shown to affect semen quality among severely poisoned individuals (Whorton, 1994), and changes in sperm characteristics were reported among Indian agricultural workers with long term exposure to ethylene dibromide (Ratcliffe et al., 1987). However, some problems in the study design and poor definition of exposure prevent meaningful interpretation of the latter report (Whorton, 1994). Serum LH concentrations were significantly increased among 54 male workers compared to 20 administrative clerks in a lindane producing factory (Tomczak et al., 1981). Blood levels of testosterone and FSH were not affected by lindane exposure in this study. Following reproductive toxicology studies in rats of molinate (a thiocarbamate herbicide used for weed control in rice fields), sperm count and reproductive history of 272 molinate formulation and production workers at three United States plants was studied, and exposure monitored (Tomenson et al., 1999). Sperm count and serum hormone levels were not related to molinate exposure nor was there evidence of reduced fertility among these workers. Also, no evidence of hormonal responses, and particularly anti-androgenic effects, was reported among 67 men exposed to vinclozolin, a widely used organic nitrogen fungicide, during synthesis and formulation operations compared to 52 controls (Zober et al., 1995). This study was set in response to concern raised by the results of animal studies, showing increased testes weight and decreased prostate, seminal vesicle and epididymis weights following oral administration of vinclozolin. More recent reports focus on an anti-androgenic effect of this fungicide during male differentiation (Monosson et al., 1999; Wolf et al., 2000), which would not be observed in an occupational setting. A Danish study of male greenhouse workers explored semen quality and sexual hormones in relation to exposure to a list of 60 pesticides (Abell et al., 2000). The most frequently reported chemicals included the insecticides pirimicarb, methomyl, deltamethrin, and endosulfan, and the fungicides benomyl, iprodione, and chlorothalonil. Only exposure to the general category of pesticides was evaluated in relation to sperm concentration, motility, morphology and viability and to plasma levels of testosterone, SHBG, FSH, and LH. None of these outcomes was affected by intensity of pesticide use. However, estimates of current dermal exposure and years of greenhouse work were inversely related to sperm concentration, motility, and viability, and to testosterone plasma levels, while the opposite was observed with the mean LH plasma level and current dermal exposure, and with the mean FSH plasma level and years of greenhouse work.

While occupational exposure to some pesticides, and particularly DBCP, may result in a definite reproductive hazard, which did not raise special public concern, a disproportionately heated debate continues in the scientific and non scientific press about the threat to human reproduction posed by environmental exposure to "endocrine disruptors". A review of 61 international studies on sperm count and semen volume combined the reported findings in a linear regression against time, and reached the conclusion that a significant decrease had occurred from 1938-1990 (Carlsen et al., 1992). A French study published thereafter reported a 2.1-2.6\% annual decrease in sperm concentration, along with a decrease in mobility and normal spermatozoa rates among healthy men volunteering for sperm donation in more recent years (Auger et al., 1995). Similar findings were reported in Scotland (Irvine, 1994), and Belgium (Van Waeleghem et al., 1994), but not in Finland (Suominen \& Vierula, 1993). It has been questioned whether these studies indicate that substantial changes in human fertility are occurring overall (Olsen, 1994), and it is questionable whether a decrease in sperm count, when still above levels of about 40 million/ml, may affect fecundability (Bonde et al., 1999). However, the connection with early and more recent observations in wildlife from contaminated areas opened the way to speculation about a role of organochlorines in causing a worldwide decline in human fertility (Sharpe, 1995; Skakkebaek et al., 1998), although temporal and spatial variability of human fertility do not seem associated with environmental exposure to DDT derivatives (Cocco, 1997; Safe, 2000). Also, it has been postulated that exposure to environmental "estrogenic" chemicals during pregnancy may induce the develop- 
ment of reproductive abnormalities (e. g. cryptorchidism and hypospadia) and a reduction in sperm count of the male offspring (Seibert, 1997). Findings among United States populations of the Great Lakes area, consuming sport fish contaminated with PCBs and chlorinated pesticides, such as DDE, hexachlorobenzene, and mirex, were contradictory (Buck et al., 1997, 2000). A significant decrease in the fecundability ratio was reported for maternal consumption of PCBs contaminated fish lasting 3-6 years in one study (Buck et al., 2000). To date, apart from the therapeutic use of diethylstilbestrol, no link with other environmental contaminants has been supported by epidemiological evidence (Pottern et al., 1997). However, this does not exclude an endocrine-etiology for some reproductive adverse effects resulting from human exposures to specific pesticides.

If occupational or environmental exposure to xenoestrogens were a plausible human reproductive toxicant through receptorial mechanisms, dose and estrogenic potential with reference to the natural estrogen would be crucial, as all experimental animal studies have confirmed. The E-screen assay has been proposed to test the estrogenic effect of chemicals on estrogen sensitive human breast cancer cell lines, such as MCF-7 cells. This test is based on the dose-related estrogen-dependent proliferation of MCF-7 cells during 6 days of culture, with reference to estradiol (Soto et al., 1995; Toppari et al., 1995). The E-screen assays produces two outcomes: (1) the relative proliferative potency (RPP), which is the ratio between the lowest estradiol concentration required to yield maximal proliferation and the lowest concentration of the test compound needed to achieve the same effect; and (2) the relative proliferative effect (RPE), which is 100 times the ratio between the maximal cell yield obtained with the test compound and that obtained with estradiol. As shown in Table 1, estradiol can induce maximal cell yields at concentrations ranging 10-100 picomoles, while xenoestrogen pesticides achieve comparable effects at doses two orders of magnitude higher than estradiol. Estradiol is produced by the ovary in the amount of $100-200 \mathrm{mg} /$ day, and it can be released by dermal patches used as hormone replacement therapy in the menopause in the amount of $50 \mathrm{mg} /$ day. The normal range of estradiol blood concentration varies in the pre-menopausal women depending on the phase of the menstrual cycle, from $30-120 \mathrm{pg} / \mathrm{ml}$ in the follicular phase, to $90-330 \mathrm{pg} / \mathrm{ml}$ in the ovulatory period, and to $65-180 \mathrm{pg} / \mathrm{ml}$ in the luteal period. Values in the post-menopausal women range $10-50 \mathrm{pg} / \mathrm{ml}$, and values in adult men range $15-70 \mathrm{pg} / \mathrm{ml}$ (Yen, 1991). Based on these results of the E-screen assay, in order to compete significantly with estradiol ER binding, $o, p$ '-DDE blood concentration would have to be $30-180 \mu \mathrm{g} / \mathrm{ml}$ in fertile women and 10 $70 \mu \mathrm{g} / \mathrm{ml}$ among post-menopausal women and men, in the absence of other interfering variables. However, reports of competitive binding assays on MCF-7 cells estimated that the $o, p^{\prime}$ DDT, $o, p^{\prime}$-DDE, and $o, p^{\prime}$-DDD (as well as $p, p^{\prime}-$ DDT, which did not bind to the rat receptor) hER affinity would be approximately 1,000-fold weaker than that of estradiol (Chen et al., 1997), i.e. about 100 times greater than with the E-screen assay. Besides, two yeast expressionreporter systems, constructed to test the ability of DDT isomers and metabolites to transactivate the hER, showed that the $o, p$ '-DDE potency of transactivating the hER or LexA-hER fusion protein is 140-300-fold weaker than that of estradiol, and that DDT isomers and metabolites, as well as other xenoestrogen pesticides, elicited an additive response when given together or with estradiol (Chen et al., 1997; Soto et al., 1995). Based on such estimates, significant estrogenic effects would become manifest for $o, p^{\prime}$-DDE blood concentrations of 4.2$54 \mathrm{ng} / \mathrm{ml}$ (or ppm) in fertile women and 1.4$21 \mathrm{ng} / \mathrm{ml}$ (or ppm) in post-menopausal women and men. With due caution for the interspecies differences, a study in rats, showing estrogenic effects at $o, p^{\prime}$-DDE concentration above $18 \mathrm{ng} / \mathrm{ml}$ (Ulrich et al., 2000), seems to be consistent with the in vitro based estimates of the order of magnitude of xenoestrogen blood level which would significantly interfere with natural estrogens.

The interference of xenoestrogens with the binding of sexual hormones to extracellular proteins, such as SHBG and $\alpha$-fetoprotein, is another factor to be considered in estimating their effective estrogenic dose (Toppari et al., 1995). It is known that methoxychlor, $o, p^{\prime}$-DDT, pentachlorophenol, and nonylphenol reduce $[3 \mathrm{H}] 17 \beta$-estradiol binding to the estrogen receptor by $10,60,20$, and $75 \%$, respectively (Danzo, 1997), which would require proportionally higher doses of the respective pesticide to significantly compete with estradiol receptorial affinity. Therefore, it seems biologically implausible that blood concentrations of xenoestrogen pesticides below the ppm range could significantly interfere with the human endocrine system through a receptorial mechanism. 


\section{Other endocrine effects of pesticides}

Pesticides may target also other endocrine glands. Toxaphene, for instance, cumulates in the rat adrenal cortex, where it inhibits ACTHstimulated corticosterone synthesis (Kuz'minskaya \& Ivanitskii, 1979; Mohammed et al., 1985). It also causes an increase in catecholamine breakdown, and unequal changes in the ratio of separate components of the sympathicoadrenalic system in tissues (Henderson et al., 1997). Besides, methyl parathion and malathion inhibit catecholamine secretion in bovine adrenal chromaffin cells (Liu et al., 1994). The pineal gland is another target of parathion toxicity, where it increased nocturnal $\mathrm{N}$-acetyl transferase (NAT) activity and serum melatonin levels in rats, acting at the level of the beta-adrenergic receptor or via the sympathetic innervation to the pineal gland (Attia et al., 1991, 1995). An inhibitory effect of parathion on gonadotrophin secretion has been reported in Bobwhite quail (Rattner et al., 1982), and fish (Singh \& Singh, 1981), but not in rats (BentueFerrer et al., 1981).

Thyroid is another frequent target for endocrine effects of pesticides. Pesticides causing thyroid disruption in wildlife and experimental animals include DDT, polyhalogenated hydrocarbons - including toxaphene (Waritz et al., 1996), and methoxychlor (Zhou et al., 1995) -, phenol derivatives, amitrole, carbaryl (Ghosh et al., 1989), ethylenthiourea and other thiocarbamates (Brucker-Davis, 1998). In most instances, thyroid disruption results from an indirect effect, leading to an increase in Thyroid Stimulating Hormone (TSH) production. Extrathyroidal sites of action were found for amitrole, a widely used herbicide, ethylenethiourea (which also results from metabolism of numerous ethylenbisdithiocarbamate fungicides), and mancozeb, which are thyroid peroxidase inhibitors, and acetochlor, clofentezine, fenbuconazole, fipronil, pendimethalin, pentachloronitrobenzene, prodiamine, pyrimethanil, thiazopyr, and toxaphene which induce hepatic metabolism and excretion of thyroid hormones (Hurley, 1998; Waritz et al., 1996). Instead, methoxychlor would inhibit iodothyronine 5'-monodeiodinase, type I (5'-ID1), the enzyme that converts thyroxine to triiodothyronine (Zhou et al., 1995), and carbaryl caused a decrease in thyroxine level in the Channa punctatus fish, accompanied by a concurrent increase in acetylcholine accumulation and T3 level, due to a significant inhibition of brain acetylcholinesterase activity (Ghosh et al., 1989). However, typical environmental concen-

\begin{tabular}{|c|c|c|c|}
\hline \multicolumn{4}{|c|}{$\begin{array}{l}\text { Estrogenic potential of some pesticides and therapeutic hormones with reference } \\
\text { to estradiol, based on the in culture "E. Screen" assay (from Soto et al., 1995). }\end{array}$} \\
\hline Compound & Concentration & RPE (\%) & RPP (\%) \\
\hline $17 \beta$-estradiol & $10 \mathrm{pM}$ & 100.00 & 100.00 \\
\hline DDT (technical grade) & $10 \mu \mathrm{M}$ & 79.61 & 0.0001 \\
\hline$O, p^{\prime}-D D T$ & $10 \mu \mathrm{M}$ & 86.14 & 0.0001 \\
\hline$P, p^{\prime}-D D T$ & $10 \mu \mathrm{M}$ & 71.00 & 0.0001 \\
\hline dieldrin & $10 \mu \mathrm{M}$ & 54.89 & 0.0001 \\
\hline Endosulfan (technical grade) & $10 \mu \mathrm{M}$ & 81.25 & 0.0001 \\
\hline 1-hydroxychlordane & $10 \mu \mathrm{M}$ & 40.00 & 0.0001 \\
\hline Kepone & $10 \mu \mathrm{M}$ & 84.00 & 0.0001 \\
\hline Methoxychlor & $10 \mu \mathrm{M}$ & 57.00 & 0.0001 \\
\hline Toxaphene & $10 \mu \mathrm{M}$ & 51.90 & 0.0001 \\
\hline
\end{tabular}

trations of potentially goitrogen chemicals did not significantly affect thyroid function among adult humans, while occupational or accidental exposure to higher levels produced only mild changes (Bogert et al., 1994).

Table 2 summarizes results of in vitro studies, animal studies, and human studies for a list of pesticides which have been evaluated in relation to their potential endocrine disrupting effect. Negative reproductive outcomes due to teratogenicity or fetotoxicity are not included. The list is limited to the compounds for which information was available from the cited references and it is not meant to be exhaustive. It could be worthwhile to remind individuals that experimental data should be used to develop prudent guidelines and to identify reproductive and other endocrine hazards before human exposure occurs, but should not be considered as a proof of adverse effects in humans (Barrett, 1992).

\section{Cancer risk associated with exposure to so-called endocrine- disrupting pesticides}

Hormones play a major role in the etiology of several human cancers, including cancer of the breast, endometrium, prostate, ovary, thyroid, bone and testis (Bogert et al., 1994). Excessive hormonal stimulation of the normal growth and function of the particular target organ may result in neoplasia independent of outside initiators, such as chemicals or ionizing radiation. Also, hormone driven cell division allows the selective proliferation of the mutated clone resulting from the initial mutagenic event. Signif- 
Table 2

Summary evaluation of pesticides with endocrine disrupting potential (EPA, 2000a, 2000b; EXTOXNET, 2000; Morgan, 1989;

Tiemann et al., 1996; Toppari et al., 1995; Traina et al., 1994; Schrader \& Cooke, 2000; Stelzer \& Chan, 1999).

\begin{tabular}{|c|c|c|c|c|}
\hline Pesticide & In-vitro studies & Animal studies & Human studies & Current uses \\
\hline \multicolumn{5}{|l|}{ Organochlorines } \\
\hline Acetochlor & & Thyroid inhibitor & & Herbicide in corn crops \\
\hline Alachlor & $\begin{array}{l}\text { Competitive aER } \\
\text { and aPR binding }\end{array}$ & $\begin{array}{l}\text { No reproductive effects } \\
\text { in adult rats }\end{array}$ & & $\begin{array}{l}\text { Herbicide in corn crops, } \\
\text { soybeans, peanuts, dry } \\
\text { beans/peas, grain sorghum, } \\
\text { and sunflowers }\end{array}$ \\
\hline $\begin{array}{l}\text { Chlordane and } \\
\text { oxychlordane }\end{array}$ & $\begin{array}{l}\text { No pro- or anti- } \\
\text { androgenic effect }\end{array}$ & Reduced fertility in rats & & Insecticide, termite control \\
\hline Chlordecone (kepone) & $\begin{array}{l}\text { Weak estrogen } \\
\text { Competitive aPR binding }\end{array}$ & Reduced fertility & Reduction in sperm quality & $\begin{array}{l}\text { Insecticide (tobacco, citrus } \\
\text { trees, ornamental shrubs, } \\
\text { bananas, ant \& roach traps) }\end{array}$ \\
\hline $\begin{array}{l}\text { DDT congeners } \\
0, p^{\prime}-D D E \\
p, p^{\prime}-D D E\end{array}$ & $\begin{array}{l}\text { Estrogen } \\
\text { Anti-androgen }\end{array}$ & $\begin{array}{l}\text { Estrogenic effects } \\
\text { thyroid inhibition }\end{array}$ & $\begin{array}{l}\text { No evidence from } \\
\text { population studies }\end{array}$ & $\begin{array}{l}\text { Insecticide for Public Health } \\
\text { purposes }\end{array}$ \\
\hline Dieldrin & $\begin{array}{l}\text { Weak estrogen } \\
\text { Weak anti-androgen }\end{array}$ & No reproductive effects & & $\begin{array}{l}\text { Insecticide (corn and } \\
\text { cotton crops) }\end{array}$ \\
\hline Endosulfan & $\begin{array}{l}\text { Weak estrogen. } \\
\text { Competitive aER and aPR } \\
\text { binding. Impaired steroid } \\
\text { synthesis in Leydig cells }\end{array}$ & $\begin{array}{l}\text { Damage to seminiferous } \\
\text { tubules in male rats and } \\
\text { reproductive organs in } \\
\text { female mice }\end{array}$ & & $\begin{array}{l}\text { Insecticide (fruits, grains, tea, } \\
\text { vegetables, tobacco, } \\
\text { and cotton) }\end{array}$ \\
\hline Heptachlor & & Reduced fertility in rats & & Insecticide, termite control \\
\hline Methoxychlor & Estrogen & $\begin{array}{l}\text { Testicular atrophy, decreased } \\
\text { sperm production and } \\
\text { testosterone levels in rats } \\
\text { and mice. Reduced fertility } \\
\text { in both genders. } \\
\text { Thyroid inhibitor }\end{array}$ & & $\begin{array}{l}\text { Insecticide (fruits, vegetables, } \\
\text { grain storage bins, mushroom } \\
\text { houses, dairies, livestock) }\end{array}$ \\
\hline Pentachlorophenol & $\begin{array}{l}\text { Weak estrogen, } \\
\text { weak anti-androgen }\end{array}$ & $\begin{array}{l}\text { No reduced fertility } \\
\text { in mice and rats }\end{array}$ & & $\begin{array}{l}\text { Biocide, wood preservative, } \\
\text { pre-harvest defoliant in cotton }\end{array}$ \\
\hline $\begin{array}{l}\text { Hexachlorocyclohexane } \\
\text { congeners }\end{array}$ & & Reduced fertility & $\begin{array}{l}\text { Changes in the levels } \\
\text { of sex hormones. }\end{array}$ & $\begin{array}{l}\text { insecticide (fruit and vegetable } \\
\text { crops, including greenhouse }\end{array}$ \\
\hline$\alpha-\mathrm{HCH}$ & Weak anti-androgen & & & vegetables, tobacco and \\
\hline$\beta-\mathrm{HCH}$ & No effect & $\begin{array}{l}\text { Weak estrogen-like effects } \\
\text { in mice and rats }\end{array}$ & & $\begin{array}{l}\text { forest crops), ointments to } \\
\text { treat head and body lice, }\end{array}$ \\
\hline$\gamma-\mathrm{HCH}$ (lindane) & $\begin{array}{l}\text { Weak anti-androgen } \\
\text { No estrogen effect } \\
\text { Impaired steroid } \\
\text { synthesis in Leydig cells }\end{array}$ & $\begin{array}{l}\text { Testicular atrophy } \\
\text { decreased sperm } \\
\text { production and testosterone } \\
\text { levels in rats and mink }\end{array}$ & & and scabies \\
\hline$\delta-\mathrm{HCH}$ & Weak anti-androgen & & & \\
\hline Mirex and photomirex & $\begin{array}{l}\text { Weak estrogen } \\
\text { No anti-androgenic effect }\end{array}$ & $\begin{array}{l}\text { Reduced fertility due to } \\
\text { testicular degeneration. } \\
\text { Affects thyroid and parathyroid }\end{array}$ & & Termiticide \\
\hline $\begin{array}{l}\text { Nonachlor } \\
\text { (cis- and trans-) }\end{array}$ & $\begin{array}{l}\text { Anti-estrogen } \\
\text { Inhibits aER binding } \\
\text { of }[3 \mathrm{H}] 17 \beta \text {-estradiol }\end{array}$ & $\begin{array}{l}\text { Sex-reversal in alligator } \\
\text { embryos, and turtles }\end{array}$ & & Termite control \\
\hline Toxaphene & $\begin{array}{l}\text { Weak estrogen. Inhibition } \\
\text { of ACTH-stimulated } \\
\text { corticosterone synthesis } \\
\text { in the adrenal cortex }\end{array}$ & Thyroid inhibitor. & & Insecticide, biocide \\
\hline
\end{tabular}

(to be continued on next page) 
Table 2 (continued from previous page)

\begin{tabular}{|c|c|c|c|c|}
\hline Pesticide & In-vitro studies & Animal studies & Human studies & Current uses \\
\hline \multicolumn{5}{|l|}{$\begin{array}{l}\text { Carbamates and } \\
\text { thiocarbamates }\end{array}$} \\
\hline Aldicarb & Weak estrogen & No reproductive effects & & Nematicide \\
\hline $\begin{array}{l}\text { Bendiocarb, } \\
\text { methomyl, } \\
\text { and oxamyl }\end{array}$ & Weak estrogens & No decrease if fertility in rats. & & $\begin{array}{l}\text { Insecticides, acaricides, } \\
\text { nematicides }\end{array}$ \\
\hline Carbaryl & Weak estrogen & $\begin{array}{l}\text { Thyroid inhibition and } \\
\text { reduced fertility in several } \\
\text { animal species }\end{array}$ & $\begin{array}{l}\text { Conflicting results on } \\
\text { reduced fecundability }\end{array}$ & Insecticide \\
\hline Carbofuran & & Testicular damage in dogs & & Broad spectrum insecticide \\
\hline Mancozeb & & Thyroid inhibitor in rats & Goitrogen & Fungicide \\
\hline Maneb and Metiram & & $\begin{array}{l}\text { Thyroid inhibitors in } \\
\text { several animal species. } \\
\text { No reproductive effects }\end{array}$ & & Fungicides \\
\hline Molinate & & Reduced fertility & No reproductive effects & Herbicide (rice crops) \\
\hline Propoxur & Weak estrogen & $\begin{array}{l}\text { Reduced fertility and } \\
\text { lactation in female rats }\end{array}$ & & Insecticide \\
\hline Thiram & & $\begin{array}{l}\text { Infertility in male mice, } \\
\text { delayed estrous cycle } \\
\text { in female mice }\end{array}$ & & Fungicide, animal repellent \\
\hline Zineb & & $\begin{array}{l}\text { Thyroid inhibitor in } \\
\text { several animal species. } \\
\text { Reduced fertility in rats. }\end{array}$ & & Fungicides \\
\hline Ziram & & $\begin{array}{l}\text { Reduced fertility in female } \\
\text { rats and mice and in male } \\
\text { rats. Testicular atrophy }\end{array}$ & & $\begin{array}{l}\text { Fungicide on almonds } \\
\text { and stone fruit }\end{array}$ \\
\hline \multicolumn{5}{|l|}{ Organophosphates } \\
\hline Chlorpyrifos & & No reproductive effects & & $\begin{array}{l}\text { Insecticide and acaricide } \\
\text { for crops and livestock }\end{array}$ \\
\hline Dimethoate & & No reproductive effects & Reduced fecundability & $\begin{array}{l}\text { Insecticide for } 40 \text { different } \\
\text { crops, lawns, termiticide } \\
\text { in buildings, pet collars. }\end{array}$ \\
\hline Methamidophos & & $\begin{array}{l}\text { Reduced number of } \\
\text { deliveries in female rats }\end{array}$ & $\begin{array}{l}\text { Reduced sperm count } \\
\text { and viability }\end{array}$ & $\begin{array}{l}\text { Insecticide, acaricide } \\
\text { and avicide }\end{array}$ \\
\hline $\begin{array}{l}\text { Methyl parathion } \\
\text { and malathion }\end{array}$ & $\begin{array}{l}\text { Inhibits catecholamine } \\
\text { secretion }\end{array}$ & $\begin{array}{l}\text { No reproductive } \\
\text { effects in rats }\end{array}$ & & $\begin{array}{l}\text { Insecticide for various crops, } \\
\text { livestock, parasite control. }\end{array}$ \\
\hline Oxydemeton-methyl & & $\begin{array}{l}\text { No reproductive } \\
\text { effects in rats }\end{array}$ & & Insecticide for various crops \\
\hline Parathion & & $\begin{array}{l}\text { Increased nocturnal } \\
\text { synthesis of melatonin. } \\
\text { Gonadotrophic hormone } \\
\text { inhibition }\end{array}$ & & Insecticides for various crops \\
\hline Trichlorfon & & $\begin{array}{l}\text { Reduced fertility and } \\
\text { increased embryonic } \\
\text { deaths in rats. }\end{array}$ & & $\begin{array}{l}\text { Insecticide for various crops, } \\
\text { livestock, parasite control }\end{array}$ \\
\hline
\end{tabular}

(to be continued on next page) 
Table 2 (continued from previous page)

\begin{tabular}{|c|c|c|c|c|}
\hline Pesticide & In-vitro studies & Animal studies & Human studies & Current uses \\
\hline \multicolumn{5}{|l|}{ Other insecticides } \\
\hline Amitraz & & Decreased fertility in rats. & & Insecticide (cotton and animals) \\
\hline Amitrole & & $\begin{array}{l}\text { Thyroid inhibitor in } \\
\text { several animal species. }\end{array}$ & & Herbicide \\
\hline Atrazine & $\begin{array}{l}\text { Weak estrogen } \\
\text { Weak anti-androgen } \\
\text { Inhibits aER binding } \\
\text { of }[3 \mathrm{H}] 17 \beta \text {-estradiol }\end{array}$ & $\begin{array}{l}\text { Damage to adrenal glands } \\
\text { Impairment of steroid } \\
\text { hormone metabolism }\end{array}$ & & $\begin{array}{l}\text { Herbicide (rice and other } \\
\text { crops) }\end{array}$ \\
\hline Azadirachtin & & $\begin{array}{l}\text { Infertility in several } \\
\text { animal species }\end{array}$ & & Insecticide \\
\hline $\begin{array}{l}\text { Benomyl (and its } \\
\text { breakdown product } \\
\text { carbendazim) }\end{array}$ & Microtubule disruptor & $\begin{array}{l}\text { Decreased sperm production } \\
\text { in adult male rats }\end{array}$ & & $\begin{array}{l}\text { Fungicide (field crops, fruits, } \\
\text { nuts, ornamentals, } \\
\text { mushrooms, and turf) }\end{array}$ \\
\hline Captan & & $\begin{array}{l}\text { Fetal loss or reduced } \\
\text { weight at birth in mice. }\end{array}$ & Reduced fecundability & $\begin{array}{l}\text { Fungicide (apple production, } \\
\text { ornamental and vegetable } \\
\text { crops) }\end{array}$ \\
\hline Clofentezine & & $\begin{array}{l}\text { Thyroid disruptor. } \\
\text { No reproductive effects }\end{array}$ & & Acaricide \\
\hline $2,4-D$ & & $\begin{array}{l}\text { No reduction in fertility. } \\
\text { Increase in thyroid and } \\
\text { ovarian weights. }\end{array}$ & Reduced fecundability & $\begin{array}{l}\text { Herbicide (wheat, rice and } \\
\text { other crops, lawn, pasture, } \\
\text { home, garden) }\end{array}$ \\
\hline Dibromochloropropane & & $\begin{array}{l}\text { Infertility in rabbits } \\
\text { (atrophy of testes) }\end{array}$ & $\begin{array}{l}\text { Infertility. Potent } \\
\text { testicular toxicant }\end{array}$ & $\begin{array}{l}\text { Insecticide (banana } \\
\text { plantations) }\end{array}$ \\
\hline Dicamba & & $\begin{array}{l}\text { No reduction in fertility } \\
\text { in rats and rabbits. }\end{array}$ & Reduced fecundability & $\begin{array}{l}\text { Herbicide (pastures, non crop } \\
\text { areas, roadways to control } \\
\text { weeds) }\end{array}$ \\
\hline Dinoseb & & $\begin{array}{l}\text { Reproductive effects } \\
\text { in rats }\end{array}$ & & $\begin{array}{l}\text { Herbicide in various field } \\
\text { crops; insecticide in grapes }\end{array}$ \\
\hline Ethylene dibromide & & $\begin{array}{l}\text { Reduced sperm } \\
\text { count in bulls }\end{array}$ & $\begin{array}{l}\text { Reduced sperm } \\
\text { count and quality }\end{array}$ & Post harvest fumigant \\
\hline Fenbuconazole & & Thyroid inhibitor & & Fungicide \\
\hline Fipronil & & $\begin{array}{l}\text { Thyroid disruptor } \\
\text { Reproductive toxicant } \\
\text { in rats }\end{array}$ & & Insecticide \\
\hline Glyphosate & & $\begin{array}{l}\text { Reproductive changes } \\
\text { at very high doses }\end{array}$ & Reduced fecundability & Herbicide \\
\hline Hexachlorobenzene & & $\begin{array}{l}\text { Decreased male fertility. } \\
\text { No estrogenic effects }\end{array}$ & & $\begin{array}{l}\text { Fungicide used to dress seed } \\
\text { and treat soil. Contaminant } \\
\text { of PCNB }\end{array}$ \\
\hline Hexazinone & & $\begin{array}{l}\text { No effects on reproduction } \\
\text { and lactation in rats }\end{array}$ & & $\begin{array}{l}\text { Herbicide in non-crop areas } \\
\text { and weed control for } \\
\text { sugarcane and pineapples }\end{array}$ \\
\hline Linuron & & No reproductive effects & & $\begin{array}{l}\text { Herbicide (soybean, cotton, } \\
\text { potato, corn, carrots, celery, } \\
\text { sorghum, and asparagus) }\end{array}$ \\
\hline Metolachlor & & $\begin{array}{l}\text { Testicular atrophy in rats. } \\
\text { No reproductive effects } \\
\text { in mice }\end{array}$ & & Herbicide \\
\hline Metribuzin & & $\begin{array}{l}\text { No reproductive effects. } \\
\text { Thyroid enlargement } \\
\text { in male rats. }\end{array}$ & & Herbicide \\
\hline
\end{tabular}

(to be continued on next page) 


\begin{tabular}{|c|c|c|c|}
\hline Pesticide & In-vitro studies & Human studies & Current uses \\
\hline Nonyl-phenol & Weak estrogen & & Molluscicide \\
\hline $\begin{array}{l}\text { Pentachloronitrobenzene } \\
\text { (PCNB) }\end{array}$ & & Thyroid inhibitor & $\begin{array}{l}\text { Fungicide used to dress seed } \\
\text { and treat soil }\end{array}$ \\
\hline Propiconazole & & No reproductive effects in rats & $\begin{array}{l}\text { Fungicide on cereals, fruit } \\
\text { and green forage crops }\end{array}$ \\
\hline Procymidone & & Anti-androgen in rats & Fungicide \\
\hline Prodiamine & & Thyroid disruptor & Herbicide \\
\hline Pyrimethanil & & $\begin{array}{l}\text { Thyroid inhibitor } \\
\text { No reproductive effects }\end{array}$ & Fungicide \\
\hline Simazine & & $\begin{array}{l}\text { No reproductive effects } \\
\text { in rats. Distrophy and necrosis } \\
\text { of germ cells in sheep. }\end{array}$ & $\begin{array}{l}\text { Herbicide, submerged weeds } \\
\text { and algae control in large } \\
\text { aquariums, ponds and fish } \\
\text { hatcheries. }\end{array}$ \\
\hline Thiazopyr & & $\begin{array}{l}\text { Thyroid disruptor } \\
\text { No reproductive effects }\end{array}$ & Herbicide \\
\hline Tributyltin & & $\begin{array}{l}\text { Short-term decrease in the } \\
\text { activity of the pituitary-thyroid } \\
\text { axis in rats. No long-term } \\
\text { effects. Pseudoermaphroditism } \\
\text { in gastropods, }\end{array}$ & $\begin{array}{l}\text { Antifouling agent on ships, } \\
\text { boats, and mariculture pen nets }\end{array}$ \\
\hline Vinclozolin & Anti-androgen & $\begin{array}{l}\text { Demasculinizing effects in rats. } \\
\text { No reproductive effects }\end{array}$ & $\begin{array}{l}\text { Fungicide (grapes, vegetables, } \\
\text { strawberries, fruit, ornamentals) }\end{array}$ \\
\hline
\end{tabular}

icant evidence exists that certain estrogens can also cause genetic alterations by mechanisms that do not involve the classical estrogen receptor (Bogert et al., 1994). The absolute frequency of these cancers is a reason for concern about cancer risk associated with medical treatment or occupational and environmental exposure to the same or closely related hormones. Experimental animal studies indicate that some estrogen mimicking pesticides might produce the same carcinogenic effects as natural or therapeutic estrogens. For instance, estrogenlike effects of methoxychlor caused a dose-related atrophy of the testes in rabbits and testicular cancer in BALB/c mice, and cancer of the ovary, pituitary, adrenals, and mammary gland in Osborne-Mendel female rats (Reuber, 1979, 1980). Hyperplasia of the mammary gland and uterus was also observed in miniature swine (Reuber, 1980). On the other hand, oral administration of DDT did not induce testicular cancer in BALB/c and C3H mice (Reuber, 1979), and inter-species differences in susceptibility to the hormonal and carcinogenic effects of methoxychlor were reported (Reuber, 1980).

Experimental evidence exists that hormonelike pesticides may stimulate cell proliferation and tumorigenesis also through mechanisms other than the classical hormonal pathways.
For instance, $p, p^{\prime}$-DDT, but not $o, p^{\prime}$-DDT, elevated tyrosine phosphorylation in c-erbB2and c-met growth factor receptors, the STAT1 alpha (p84/91) signal transduction indicator, and 3H thymidine incorporation in human breast epithelial MCF-10A cells at physiologically relevant concentrations, such as 10nM (Shen \& Novak, 1997). However, only cancer sites for which hormonal mechanisms have been postulated are herein considered.

\section{Breast cancer}

The role of hormones in breast cancer etiology is consistent with the hypothesis that breast cell proliferation is estrogen-dependent (Bogert et al., 1994). Polymorphisms of genes involved in estrogen secretion and metabolism, such as:

a) the 17B-hydroxysteroid dehydrogenase 2 (EDH17B2) gene encoding the 17B-hydroxysteroid dehydrogenase enzyme, which converts estrone (E1) into estradiol (E2);

b) the cytochrome P450c17a (CYP17) gene, which controls certain rate limiting steps in estrogen biosynthesis; and

c) the estrogen receptor gene, encoding the estrogen receptor which binds and transactivates estrogen into DNA for transactivation of estrogen responsive genes, might account for 
geographic variation in breast cancer incidence. All these metabolic steps may be also affected by xenobiotics, thus leading to an excess or a decrease in estrogen stimulation of the target breast cells. These indirect effects may contribute to, or may decrease the effect of direct receptorial stimulation.

A population-based case control study in British Columbia reported an excess breast cancer risk among women (pre- and postmenopausal ages combined) employed as crop and fruit and vegetable farmers, with a reasonably likely exposure to numerous pesticides (Band et al., 2000). Occupational exposure to pesticides was also significantly associated with a 4-fold increase in breast cancer risk in Serbia (Kocic et al., 1996), and risk was also elevated among Chinese women with some probability of high level pesticide exposure, although this finding was based on a small number of exposed (Petralia et al., 1998). Female breast cancer mortality and incidence was not increased among Florida licensed pesticide users (Fleming et al., 1999a, 1999b), while a case-control study on occupational risk of male breast cancer did not find an association with exposure to herbicides and other pesticides (Cocco et al., 1998). Also, agricultural occupations were not included among high risk occupations for breast cancer in Swedish women (Pollan \& Gustavsson, 1999). In most of these studies, exposure to pesticides was largely hypothetical, based on occupational titles or derived from working histories. Studies measuring pesticide residuals in body fluids or tissues as markers of internal dose of exposure are supposed to provide a more precise definition of exposure. Besides, as stated above, exposure to pesticide mix, resulting from numerous different chemicals, which change rapidly on a yearly base, is the norm in agricultural settings, making it difficult to identify the potential risk factor. On the other hand, by definition, studies using markers of internal dose are aimed to identify associations with specific compounds or their derivatives, and only chemicals for which specific tests are available may be identified. Therefore, it is uncertain how to interpret contradictory findings, whether in relation to random variation in the response to the known chemical, or to changes in the associated chemicals, or factors responsible for the increase in risk. Most such reports focused on the association between organochlorines, particularly DDT derivatives, and breast cancer. A large number of such studies have been published, on the wave of few positive reports. Table 3 summarizes their results.
A vast amount of scientific effort and resources have been dedicated to explore the risk of breast cancer associated with the internal dose of DDT derivatives. Among the 29 studies reported in Table 2, the majority $(21 / 29)$ yielded negative results, and only $5 / 29$ found a significant excess risk, ranging 2-5 fold (a ninefold increase was reported in a small study for ER+ mammary cancer - Dewailly et al., 1994). A logical conclusion would be that there is not epidemiological evidence that the internal dose of DDT derivatives, mostly $p, p^{\prime}$-DDE, is associated with an increase in breast cancer risk. Such a conclusion fits with the current experimental knowledge about $p, p^{\prime}$-DDE as a potent anti-androgen (Kelce et al., 1995). The estrogen derivative, $o, p^{\prime}$-DDE, derives from $o, p^{\prime}-$ DDT, which is only a contaminant of technical grade DDT (IARC, 1991). $o, p^{\prime}$-DDT concentration may vary according to the producer, but is usually much lower than the $p, p$ ' isomer. As a consequence, $o, p^{\prime}$-DDE is frequently below the limit of detection in population studies, which would exclude a significant contribution in increasing breast cancer risk. On the other hand, we cannot exclude a possible role of $o, p^{\prime}$-DDE in breast cancer etiology, if such exposure would occur at a high level.

The body burden of other organochlorines has been measured in relation to breast cancer risk. High dieldrin serum concentrations were associated not only with a 2 -fold increase in breast cancer risk (Wolff et al., 2000b), but also with poor prognosis among breast cancer patients (Hoyer et al., 2000a). Findings were less suggestive for hexachlorobenzene (HCB). HCB breast adipose tissue levels did not differ significantly between incident breast cancer cases and non cancer controls (Aronson et al., 2000; Dewailly et al., 1994; Falck Jr. et al., 1992; Zheng et al., 1999a), although they were slightly more elevated among ER+ breast cancer cases compared to ER- cases, and to controls (Dewailly et al., 1994; Zheng et al., 1999b). A non significantly elevated risk was found only among nulliparous women, for the third tertile when compared with the lowest. No excess was observed among parous women, or for premenopausal or postmenopausal breast cancer (Zheng et al., 1999b). In another study, women in the upper three quartiles of HCB serum level were at twice the risk of breast cancer, compared to those in the lowest quartile (Dorgan et al., 1999). However, there was no evidence for a dose-response relationship, and the association was limited to women whose blood was collected close to the time of diagnosis. In a third study, only postmenopausal women 
Studies of breast cancer in relation to biomarkers of internal DDT exposure.

\begin{tabular}{|c|c|c|c|c|c|}
\hline First author and year & Body fluid/tissue & $\begin{array}{l}\# \text { of cases } \\
\text { and controls }\end{array}$ & Country & $\begin{array}{l}\text { DDE concentration } \\
\text { (cases vs controls) }\end{array}$ & Risk \\
\hline Wassermann et al. (1976) & Mammary adipose tissue & $9 / 5$ & Brazil & 2.0 vs $4.3 p p m$ & Not evaluated \\
\hline Unger et al. (1984) & Mammary adipose tissue & $14 / 21$ & Denmark & 1.23 vs $1.25 \mathrm{ppm}$ & No association \\
\hline Mussalo-Rauhamaa et al. (1990) & Mammary adipose tissue & $41 / 33$ & Finland & 960 vs 980ppb & No association \\
\hline Falck Jr. et al. (1992) & Mammary adipose tissue & $20 / 20$ & United States & 1887 vs $1174 \mathrm{ppb}$ & Non significant excess \\
\hline Wolff et al. (1993) & Serum & $58 / 171$ & United States & 11.0 vs $7.7 \mathrm{ng} / \mathrm{ml}$ & 4-fold excess \\
\hline Dewailly et al. (1994) & Mammary adipose tissue & $20 / 17$ & Canada & $\begin{array}{l}\text { 2131.2ppb (ER + cases) } \\
\text { vs 608.9ppb (ER - cases) } \\
\text { vs 765.3ppb (controls) }\end{array}$ & 9-fold excess (ER + cases) \\
\hline Krieger et al. (1994) & Serum & $150 / 150$ & United States & 43.3 vs $43.1 \mathrm{ppb}$ & No association \\
\hline Van't Veer et al. (1997) & Adipose tissue & $265 / 341$ & Europe & $1.35 \mu \mathrm{g} / \mathrm{g}$ vs $1.51 \mu \mathrm{g} / \mathrm{g}$ & Significant decrease \\
\hline López-Carrillo et al. (1997) & Serum lipids & $141 / 141$ & Mexico & 562.5 vs $505.5 \mathrm{ppb}$ & No association \\
\hline Hunter et al. (1997) & Plasma & $236 / 236$ & United States & 4.71 vs $5.35 p p b$ & Non significant decrease \\
\hline Schecter et al. (1998) & Serum & $21 / 21$ & Vietnam & 12.17 vs $16.67 \mathrm{ng} / \mathrm{ml}$ & No association \\
\hline Moysich et al. (1998) & Serum lipids & $154 / 192$ & United States & 11.47 vs $10.77 \mathrm{ng} / \mathrm{ml}$ & Non significant excess \\
\hline Guttes et al. (1998) & Breast tissue & $45 / 20$ & Germany & 805 vs 496ng/g & Not evaluated \\
\hline Liljegren et al. (1998) & Adipose tissue & $43 / 35$ & Sweden & 767 vs $1,026 n g / g$ & No association \\
\hline Olaya-Contreras et al. (1998) & Plasma & $153 / 153$ & Colombia & 3.3 vs $2.5 p p b$ & 2-fold excess \\
\hline Hoyer et al. (1998) & Serum lipids & $240 / 477$ & Denmark & $1,168.2$ vs $1,185.4 \mathrm{ppb}$ & No association \\
\hline Dorgan et al. (1999) & Serum & $105 / 525$ & United States & $\begin{array}{l}\text { Controls: } 16.3 \mathrm{ng} / \mathrm{ml} \\
\text { Cases: lower but not given }\end{array}$ & No association \\
\hline Helzlsouer et al. (1999) & Serum lipids & $346 / 346$ & United States & $1,698.9$ vs $1,920.3 \mathrm{ng} / \mathrm{g}$ & Inverse association \\
\hline Mendonça et al. (1999) & Serum & $177 / 350$ & Brazil & $5.1 \mathrm{vs} 4.8 \mathrm{ng} / \mathrm{ml}$ & No association \\
\hline Zheng (1999b) & Adipose tissue & $304 / 186$ & United States & 736.5 vs $784.1 \mathrm{ppb}$ & No association \\
\hline Aronson et al. (2000) & Adipose tissue & $217 / 213$ & Canada & 693 vs $596 \mu \mathrm{g} / \mathrm{Kg}$ & No association \\
\hline Bagga et al. (2000) & Adipose tissue & $73 / 73$ & United States & 800.0 vs $709.1 \mathrm{ng} / \mathrm{g}$ & No association \\
\hline Demers et al. (2000) & Plasma lipids & $315 / 526$ & Canada & $\begin{array}{l}508.9 \text { vs } 426.7 \text { (Hosp. } \\
\text { Ctrls) and } 480.4 \mu \mathrm{g} / \mathrm{kg} \\
\text { (Pop. Ctrls) }\end{array}$ & $\begin{array}{l}37 \% \text { excess with Hosp } \\
\text { Ctrls. } 64 \% \text { excess for } \\
\text { large tumors. } 2.9 \text {-fold } \\
\text { excess for lymphnode } \\
\text { involvement }\end{array}$ \\
\hline Hoyer et al. (2000b) & Serum lipids & $155 / 274$ & Denmark & $1,229.8$ vs $1,171.6 p p b$ & $\begin{array}{l}\text { 3-fold excess for } \\
p, p^{\prime}-D D T \\
\text { no excess for } p, p^{\prime}-D D E\end{array}$ \\
\hline Romieu et al. (2000) & Serum lipids & $120 / 126$ & Mexico & 3.84 vs $2.51 \mu \mathrm{g} / \mathrm{g}$ & $\begin{array}{l}\text { Postmenopausal: 5-fold } \\
\text { excess. Premenopausal: } \\
\text { 2-fold excess. }\end{array}$ \\
\hline Wolff et al. (2000a) & Serum lipids & $175 / 355$ & United States & 0.61 vs $0.66 \mu \mathrm{g} / \mathrm{g}$ & No association \\
\hline Wolff et al. (2000b) & Serum lipids & $148 / 295$ & United States & 977 vs $1 \backslash 100 \mathrm{ng} / \mathrm{g}$ & No association \\
\hline Zheng et al. (2000) & Serum & $475 / 502$ & United States & 460.1 vs $456.2 \mathrm{ppb}$ & No association \\
\hline
\end{tabular}

showed a non significant increase in breast cancer risk associated with HCB fat concentrations around 40ng/g, but postmenopausal women with ER+ tumours showed a 7 -fold increase in risk (Liljengran et al., 1998). On the other hand, limited evidence of an adverse effect of serum levels of HCB and mirex, another chlorinated insecticide, only for women who ever lactated was observed in another U. S. study (Moysich et al., 1998). Higher $\beta$-Hexachlorocyclohexane $(\mathrm{HCH})$ plasma levels were associated with an increase in breast cancer risk in three studies (Aronson et al., 2000; Hoyer et al., 1998; Mussalo-Rauhamaa et al., 1990). However, lower $\beta$-HCH concentrations were reported in the breast adipose tissue of cancer patients than in tissue from women with benign disease in a German study (Guttes et al., 1998). Other pesticides were evaluated in individual studies. A Canadian study reported positive findings for oxychlordane and transnonachlor (Demers et al., 2000), while triazine 
herbicides showed a positive association with breast cancer incidence in an ecological study among Kentucky counties in the United States (Kettles et al., 1997).

Only DDT derivatives have been extensively investigated thus far. In the overall evaluation, results have been negative. However, studies should address more specifically the hypothesis on whether a receptorial and/or non receptorial mechanism is implicated. If a receptorial mechanism is hypothesised, the most estrogenically effective pesticides should be investigated, including the $o, p^{\prime}$ - DDT isomer and its derivative $o, p^{\prime}$-DDE, as well as other pesticides with significant estrogenic power, particularly in relation to $\mathrm{ER}+$ neoplasms in the breast and other sites as well.

\section{Endometrial cancer}

The major demographic characteristics of endometrial cancer, as well as the major non demographic risk factors, are explained on the basis of cumulative exposure of the endometrium to the so-called unopposed estrogen fraction, which is not counterbalanced by the modifying influences of progesterone. Low parity is the major established risk factor for endometrial cancer, as no endometrial mitotic activity occurs during pregnancy, due to the persistent high progesterone levels. Oral contraceptives, that expose the endometrium to constant high levels of both estrogen and progestogen, should also protect against endometrial cancer development, while estrogen replacement therapy and obesity should increase risk. All of these predicted effects have been repeatedly well documented in epidemiological studies (Bogert et al., 1994). Obese postmenopausal women have increased plasma concentration of estradiol, as adipose tissue converts androstenedione to estrone, which in turn can be converted directly to estradiol. In addition, SHBG levels are lower in obese women, so that their amount of bioavailable estradiol is higher than would be expected from the peripheral conversion of androstenedione to estrone alone (Bogert et al., 1994). Therefore, also xenoestrogens might add their effect to natural estrogen playing a role in the development of endometrial cancer.

Only a few studies, however, have specifically addressed the issue. No excess in endometrial cancer risk associated to increasing quartiles of serum concentrations of $p, p^{\prime}$-DDE was observed in a multicentre case-control study conducted in five geographic regions of the United States (Sturgeon et al., 1998). Also, blood concentration of various chlorinated pesticides was not associated with an increase in endometrial cancer risk (Weiderpass et al., 2000), or with diagnosis of endometriosis (Lebel et al., 1998). Endometriosis is a relatively frequent disorder characterized by the growth of endometrial tissue in abnormal locations, most frequently in the ovary (Perloe, 2000), which is associated with an increased ovarian cancer risk (Ness et al., 2000).

\section{Ovarian cancer}

It is proposed that the epithelial cells within the developing follicle or covering the ovarian surface, which replicate during or after each ovulation, are the cells of origin for ovarian cancer (Bogert et al., 1994). Thus, any respite from ovulation would be protective against ovarian cancer, as supported by epidemiological results showing that the ovarian cancer risk decreases with increasing parity, combination oral contraceptive use (Bogert et al., 1994), and lactation, at least for ovarian cancers occurring in the premenopausal age (Daly \& Obrams, 1998; Riman et al., 1998; Siskind et al., 1997). Triazine herbicides, which have shown weak estrogen and anti-androgen effects in in vitro studies (Table 1), have been associated to a 2.7 4.4-fold increase in ovarian epithelial cancer in two Italian case-control studies (Donna et al., 1984, 1989). These results need to be replicated and the carcinogenic mechanism elucidated before drawing conclusions.

\section{Prostate cancer}

Although the relationship between testosterone levels and the rate of cell proliferation in the prostate is unstudied, and epidemiological studies of circulating testosterone levels and prostate cancer risk yielded conflicting results, it is well known that its metabolic product, dihydrotestosterone, controls mitotic activity in the prostate, by binding to the androgen receptor $(\mathrm{AR})$ and being then translocated to the nucleus of prostate cells for DNA binding and transactivation of androgen responsive genes (Bogert et al., 1994). All clearly established experimental models of prostate cancer have an androgen requirement for tumor induction. The AR, which is the product of the AR gene located on the long arm of the $\mathrm{X}$ chromosome, is crucial for androgen activity in the prostate. The frequency of AR gene polymorphisms, that transactivate subnormally an androgen responsive reporter gene, vary between populations consistently to vari- 
ations in prostate cancer incidence (Bogert et al., 1994).

Occupational and environmental exposure to pesticides potentially interacting with free testosterone bioavailability, and/or its AR binding, might be relevant for prostate cancer risk. Such exposures are more likely to occur among agricultural workers or for the general population living in rural areas, or around chemical factories, where pesticides are used, manufactured and/or processed. Reviews of the epidemiological literature on the occupational risk for prostate cancer have indicated an excess among farmers (Blair et al., 1985; Keller-Byrne et al., 1997; van der Gulden \& Vogelzang, 1996). A meta-analysis of 24 studies which examined the association of prostate cancer with farming found a weak positive association overall. The observed excess resulted mainly from retrospective case-control studies, it was not affected by the year of publication, and it was not explained by the possible confounders (Keller-Byrne et al., 1997). The interpretation to be given to these findings also varies by the attitude of the author, and the use of agricultural chemicals is among the considered hypotheses (Keller-Byrne et al., 1997; van der Gulden \& Vogelzang, 1996). More recent reports have not provided more consistent findings. A two-fold excess prostate cancer risk among United States farmers was restricted to short-term workers and workers in crop production, and it was not limited to those who began farming after the widespread introduction of pesticides use (Krstev et al., 1998). Dutch farm laborers who worked between 1960 and 1970 had a significant increase in prostate cancer risk, and they significantly differed from workers who had controls for spraying pesticides more days per year (van der Gulden et al., 1995). Farming employment was the most prominent positive association in another United States case-control study, where patients affected by benign prostate hyperplasia were the controls (Checkoway et al., 1987), and in an occupational survey in British Columbia, using cancer patients (all other sites but lung) as the controls (Band et al., 1999). However, although exposure to herbicide and pesticides was more common among cancer patients, ages when starting farm work, years worked, hours of farm work per week, and proportion of exposed to pesticides and herbicides did not differ between cases and controls who reported ever being employed on a farm. Therefore, the authors concluded that occupational exposures in farming did not account for the observed association (Checkoway et al., 1987). In a Canadian study, more detailed occupational information suggested a weak, but significant excessive prostate cancer mortality with the number of acres sprayed with herbicides in the 1970 's, while no other farm exposures evaluated in this study was associated with an increase in prostate cancer risk (Morrison et al., 1993). In a German case-control study of 192 histologically confirmed prostate cancer cases, however, the only reported occupational risk factor was having worked in transportation or communication activities (Heiskel et al., 1998). It is not clear from this small study whether driving was the risk factor. If it were, the hypothesis should be considered also among farmers, as driving tractors and heavy duty agricultural machines in unpaved country roads is an important part of agricultural work, and therefore a possible confounder in the studies of pesticide use and prostate cancer.

Cohort studies of pesticide applicators show somewhat more consistent positive findings, with a two-fold increase in mortality from (Fleming et al., 1999a) and the incidence of prostate cancer (Fleming et al., 1999b) in Florida. A $26 \%$ excess in a proportional mortality study of Iowa farmers (Cerhan et al., 1998), and a small but significant $13 \%$ excess incidence in a large Swedish cohort of licensed pesticide applicators in agriculture, which was more elevated among those born in 1935 or later. In the opinion of the authors, this would corroborate the hypothesis of a link with agrochemicals or other risk factors in farming (Dich \& Wiklund, 1998).

In contrast with occupational studies, where heterogeneous exposures are accumulated into definitions such as "farmers", "pesticides" or - at best - "herbicides", some environmental epidemiology studies evaluating hormone-related cancer risk focused on specific chemicals. On the other hand, conducting studies at the population level exposes the effect of the socalled "ecological bias" (Morgenstern, 1982). Such a bias results in a dilution of the risk estimate in case of a true positive association, as there is no way of distinguishing within a general population various degrees of exposure, if they are not related to physical and measurable entities, such as distance from the source. Although in a study of 24 non human primates, fed with $20 \mathrm{mg} / \mathrm{Kg}$ DDT daily for more than 10 years, one out of the two tumors observed was a well-differentiated adenocarcinoma of the prostate (Takayama et al., 1999), environmental exposure to DDE, the most persistent DDT derivative, as derived from early measurements in the adipose tissue of population samples in 
22 states of the United States, did not show a positive correlation with prostate cancer mortality (Cocco \& Benichou, 1998). In fact, those results might suggest a negative correlation if any, a paradox which could be biologically plausible, due to the anti-androgenic properties of the main DDE isomer, the $p, p^{\prime}$ isomer, in experimental models (Kelce et al., 1995). Pounds of atrazine and captan applied annually in Central California counties showed a good correlation ( $r=0.67$ and 0.49 , respectively) with incidence of prostate cancer (Mills, 1998). A small increase in prostate cancer mortality was observed in the surroundings of a pesticide factory in United Kingdom, but a link was excluded as there was not an indication of a decline with distance from the factory (Wilkinson et al., 1997). 2,3,7,8 tetrachlorodibenzo-p-dioxin (TCDD) is a frequent contaminant of widely used herbicides. TCDD-related anti-estrogenic effects have been described in experimental animals as well as in MCF-7 human breast cancer cell cultures (Safe et al., 1991). As estrogentreatment of prostate neoplasms is a therapeutic strategy, a possible link of exposure to antiestrogen herbicides and prostate cancer risk was enviseged (Keller-Byrne et al., 1997). However, the 15-year mortality experience among the population of the TCDD-contaminated area after the Seveso accident in Italy, did not show any increase in prostate cancer deaths (Bertazzi et al., 1997), while the complex interaction of TCDD with the endocrine system, along with its cardiovascular and immune toxicity, was tentatively considered as a plausible explanation for the excess mortality from cardiovascular diseases and diabetes in this population (Pesatori et al., 1998).

It seems plausible that occupational exposure to very high concentrations of some pesticides, particularly those which bio-concentrate in fat, might affect prostate cancer risk (KellerByrne et al., 1997). However, assuming exposure to pesticide concentrations high enough to compete with natural hormones in linking specific receptors and disrupt significantly their effect, it is also plausible that an increase or decrease in risk might result; depending on the specific type of hormone-like mechanism involved. Therefore, more research should be devoted to inquiry into specific chemicals, or well defined mixtures, and specific toxicological mechanisms affecting prostate cancer risk.

\section{Testicular cancer}

Some epidemiological characteristics of testicular cancer suggest a role for in utero estrogen exposure in the etiology of this tumor. Apart from the characteristic peak incidence rate in early adult life, in a pattern that is similar to that of DES-induced vaginal adenocarcinoma, cryptorchidism, maternal nausea and maternal obesity, both related to excess free maternal estrogen during the critical gestation period, these are known risk factors for testicular cancer (Bogert et al., 1994). Such a hypothesis was confirmed in a recent large case-control study in which xenoestrogen exposure during pregnancy was associated with a 4 -fold increase in the risk of primary malignant germcell testicular cancer among residents in Ontario aged 16-59 (Weir et al., 2000). The hypothesis that parental exposure to estrogen-mimicking pesticides could play a role in testicular cancer etiology among youngsters was tested in a large cohort study of children born from 1952-1991 to Norwegian farmers (Kristensen et al., 1996). However, while a higher than expected incidence of testicular cancer was observed, the excess was related to use of fertilizers, particularly for non-seminoma neoplasms. Therefore, the authors raised the hypothesis of a role of excess run-off nutrients from agricultural areas instead of endocrine disruption as the underlying mechanism (Kristensen et al., 1996). Some indication of a species-specific response of the Leydig cells of the testicular interstitium to the stimulation of the luteinizing hormone (LH), following administration of the fungicide procymidone, is provided by experimental studies in rats and mice (Murakami et al., 1995). This could account for the different sensitivity across species to the procymidone-induced Leydig cell tumorigenesis. Within species differences might be related to genetic polimorphisms, such as the overexpression of aromatase, which might result in itself the increased estrogen production, leading to the induction of testicular cancer (Fowler et al., 2000).

The finding of an excessive risk of testicular seminoma and testicular dysfunction among United States military dogs serving in Vietnam, coupled with a decrease in sperm count among United States Vietnam veterans, suggested a role of phenoxy herbicides in testicular cancer etiology (Hayes et al., 1990). On the other hand, a 2.5-fold increase in testicular cancer incidence was reported among Florida licensed pesticide applicators, but, although this result would add to the evidence supporting a role of endocrine disrupting pesticides, the lack of soft tissue sarcomas in this cohort was considered at odds with a role of phenoxy herbicides (Fleming et al., 1999b). Also, an elevated risk of testicular cancer among Swedish licensed 
pesticide applicators, reported in an early paper (Wiklund et al., 1986), was not confirmed in the extended follow-up (Dich et al., 1996). Geographical studies provided limited support for an excess of surgical correction of cryptorchidims (orchidopexy), a condition strongly associated with testicular cancer risk, in Spanish areas with more intensive farming (GarciaRodriguez et al., 1996). No specific agricultural chemicals have been investigated in relation to testicular cancer risk, using an analytical study design. An ecological study of testicular cancer mortality in relation to DDE body burden in population samples of 22 states of the United States (Cocco \& Benichou, 1998) did not support the hypothesis of an involvement of this chemical in causing the repeatedly reported rising incidence of this tumor (Ekbom et al., 1996; Skakkebaek et al., 1998).

\section{Thyroid cancer}

As TSH is the principal hormone regulating the growth and function of the thyroid gland, any mechanism by which elevated TSH levels are achieved may be of etiologic relevance in the development of thyroid cancer (Bogert et al., 1994). For instance, history of pregnancy, during which thyroid gland activity is increased, is associated with elevated thyroid cancer risk. Other therapeutic or environmental conditions, such as blocking thyroid hormone synthesis, administering TSH directly, an iodine-deficient diet, or environmental exposure to chemical goitrogens, including a few pesticides, may also affect the thyroid function thus contributing to an increase in thyroid cancer risk (Bogert et al., 1994). Thyroid is a frequent target for carcinogenic pesticides in experimental studies. Ten percent of pesticides screened for carcinogenicity by the Environmental Protection Agency, United States (EPA, 2000a, 2000b), produced thyroid follicular cell tumors in rodents, but mutagenicity seemed to be relevant only for acetochlor (Hurley, 1998; Mattioli et al., 1994), and amitrole. Amitrole is metabolized to mutagenic intermediates by peroxidases, including prostaglandin synthetase, and lactoperoxidase, a model for thyroid peroxidase (Bogert et al., 1994). Epigenetic mechanisms are suspected as intrathyroidal and extra-thyroidal sites of action were reported for numerous pesticides which induce hepatic metabolism and excretion of thyroid hormones (Hurley, 1998).

\section{Conclusions}

In conclusion, scientific evidence exists that DCMP, chlordecone, and maybe a few other pesticides, affect human reproduction, while amitrole and mancozeb are thyroid inhibitors. As it concerns other pesticides, results are either negative, or they are contradictory, or, when positive, they are observed only at very high doses in experimental animals, or simply they have not been studied. Whether human exposure to the broad category of pesticides should be regarded as a risk factor for hormone-dependent cancers and endocrine disruptive effects is still unclear. In fact, there is not conclusive evidence for such effects following occupational and environmental exposure to pesticides, as contradictory findings reflect the extraordinary heterogeneity of exposures within the category. On the other hand, there is evidence of an adverse effect of some pesticides on the human endocrine system, while others require further investigation for a possible etiologic role in some hormone-dependent cancers. From the perspective of prevention, to keep using the broad definition of pesticides in epidemiological studies does not help to identify the responsible agent. Indeed, the complexity of exposures results in dilution of effects, as most individual compounds are not studied in this regard, most might be ineffective as endocrine disruptors or carcinogenic agents, or there might be opposite effects. Also, apart from receptorial mechanisms, other nonreceptorial mechanisms may plausibly play a role in endocrine disruption and hormone-dependent cancer, and individual chemicals should be evaluated in this regard.

As far as specific chemicals are concerned, DDT is the most studied chemical in this respect. This chemical was banned almost 30 years ago in developed countries, and it is currently used only in developing countries against malaria, because it is still effective and inexpensive. While a precautional world-wide ban of its agricultural uses is reasonable, banning its use for Public Health purposes is not, as the certainty of its anti malarial effectiveness is not balanced by the uncertainty of the resulting benefits. Indeed, it seems contradictory to attribute to this compound, whose body burden in humans is steadily decreasing, the responsibility of a hypothetical parallel worldwide reduction in male fertility or increase in testicular cancer incidence (Cocco, 1997; Ekbom et al., 1996; Safe, 2000).

Experimental and animal studies underscore an ecological problem, which is a serious 
one in itself, as well as a reason for concern, restriction, and control of the proper use of such chemicals. Studies in wildlife, however, seldom correspond to the standards required to the epidemiological and experimental work in terms of study design and analysis, which allow researchers to test the same hypothesis under the same or similar conditions before establishing conclusive remarks. More sound scientific work is needed to prevent ecological and human adverse effects, including endocrine effects, resulting from improper use of pesticides or from proper use of hazardous chemicals.

\section{References}

ABELL, A.; ERNST, E. \& BONDE, J. P., 2000. Semen quality and sexual hormones in greenhouse workers. Scandinavian Journal of Work, Environment \& Health, 26:492-500.

ARONSON, K. J.; MILLER, A. B.; WOOLCOTT, C. G.; STERNS, E. E.; McCREADY, D. R.; LICKLEY, L. A.; FISH, E. B.; HIRAKI, G. Y.; HOLLOWAY, C.; ROSS, T.; HANNA, W. M.; Sen GUPTA, S. K. \& WEBER, J. P., 2000. Breast adipose tissue concentrations of polychlorinated biphenyls and other organochlorines and breast cancer risk. Cancer Epidemiology, Biomarkes \& Prevention, 9:55-63.

ATTIA, A. M.; MOSTAFA, M. H.; RICHARDSON, B. A. \& REITER, R. J., 1995. Changes in nocturnal pineal indoleamine metabolism in rats treated with parathion are prevented by beta-adrenergic antagonist administration. Toxicology, 97:183-189.

ATTIA, A. M.; REITER, R. J.; STOKKAN, K. A.; MOSTAFA, M. H.; SOLIMAN, S. A. \& EL-SEBAE, A. K., 1991. Parathion (O,O-dimethyl-O-p-nitrophenyl phosphorothioate) induces pineal melatonin synthesis at night. Brain Research Bulletin, 26:553-557.

AU, W. W.; SIERRA-TORRES, C. H.; CAJAS-SALAZAR, N.; SHIPP, B. K. \& LEGATOR, M. S., 1999. Cytogenetic effects from exposure to mixed pesticides and the influence from genetic susceptibility. Environmental Health Perspectives, 107:501-505.

AUGER, J.; KUNTSMANN, J. M.; CZYGLIK, F. \& JOUANNET, P., 1995. Decline in semen quality among fertile men in Paris during the past 20 years. New England Journal of Medicine, 332:281-285.

BAGGA, D.; ANDERS, K. H.; WANG, H. J.; ROBERTS, E. \& GLASPY, J. A., 2000. Organochlorine pesticide content of breast adipose tissue from women with breast cancer and control subjects. Journal of the National Cancer Institute, 92:750-753.

BAIRD, D. D.; WILCOX, A. J. \& WINBERG, C. R., 1986. Use of time to pregnancy to study environmental exposures. American Journal of Epidemiology, 124:470-480.

BAND, P. R.; LE, N. D.; FANG, R.; THRELFALL, W. J. \& GALLAGHER, R. P., 1999. Identification of occupational cancer risks in British Columbia. Part II: A population-based case-control study of 1516 prostatic cancer cases. Journal of Occupational and Environmental Medicine, 41:233-247.
BAND, P. R.; LE, N. D.; FANG, R.; DESCHAMPS, M. \& GALLAGHER, R. P., 2000. Identification of occupational cancer risks in British Columbia. A population-based case-control study of 995 incident breast cancer cases by menopausal status, controlling for confounding factors. Journal of Occupational and Environmental Medicine, 42:284310.

BARRETT, J. C., 1992. Mechanisms of action of known human carcinogens. In: Mechanisms of Carcinogenesis in Risk Identification (H. Vainio, P. N. Magee, D. B. McGregor \& A. J. McMichael, ed.), IARC Scientific Publication 116, pp. 115-134, Lyon: International Agency for Research on Cancer.

BENTUE-FERRER, D.; ALLAIN, H.; REYMANN, J. M. \& VAN DEN DRIESSCHE, J., 1981. Effets de trois biocides: Le demethoate, le parathion ethyl et le zinebe sur l'equilibre neuro endocrinien du rat femelle. Toxicological European Research, 3:279283

BERTAZZI, P. A.; ZOCCHETTI, C.; GUERCILENA, S.; CONSONNI, D.; TIRONI, A.; LANDI, M. T. \& PESATORI, A. C., 1997. Dioxin exposure and cancer risk: A 15-year mortality study after the "Seveso accident". Epidemiology, 8:646-652.

BLAIR, A.; MALKER, H.; CANTOR, K. P.; BURMEISTER, L. \& WIKLUND, K., 1985. Cancer among farmers. A review. Scandinavian Journal of Work, Environment \& Health, 11:397-407.

BOGERT, C. J.; STRAUSS, M. A. \& HARBISON, R. D., 1994. Reproductive toxicology and occupational exposure. In: Occupational Medicine (C. Zenz, O. B. Dickerson \& E. P. Horvath Jr., ed.), pp. 836-869, $3^{\text {rd }}$ Ed. St Louis: Mosby-Year Book, Inc.

BONDE, J. P. E.; HJOLLUND, N. H. I.; KOLSTAD, H. A.; ABELL, A. \& LARSEN, S. B., 1999. Environmental semen studies - Is infertility increased by a decline in sperm count? Scandinavian Journal of Work, Environment \& Health, 25(Sup. 1):12-16.

BRITTON, W. M., 1975. Influence of high levels of DDT in the diet on liver microsomal estrogen metabolism in the laying hen. Bulletin of Environmental Contamination and Toxicology, 13:698702 .

BRUCKER-DAVIS, F., 1998. Effects of environmental synthetic chemicals on thyroid function. Thyroid, 8:827-856. 
BUCK, M. G.; SEVER, L. E.; MENDOLA, P.; ZIELENY, M. \& VENA, J. E., 1997. Consumption of contaminated sport fish from lake Ontario and time to pregnancy. New York State Angler Cohort. American Journal of Epidemiology, 146:949-954.

BUCK, M. G.; VENA, J. E.; SCHISTERMAN, E. F.; DMOCHOWSKI, J.; MENDOLA, P.; SEVER, L. E.; FITZGERALD, E.; KOSTYNIAK, P.; GREIZERSTEIN, H. \& OLSON, J., 2000. Parental consumption of contaminated sport fish from lake Ontario and predicted fecundability. Epidemiology, 11:388-393.

BULGER, W. H. \& KUPFER, D., 1983. Effect of xenobiotic estrogens and structurally related compounds on 2-hydroxylation of estradiol and on other monooxygenase activities in rat liver. Biochemical Pharmacology, 32:1005-1010.

BULGER, W. H.; MUCCITELLI, R. M. \& KUPFER, D., 1978. Interactions of chlorinated hydrocarbon pesticides with the $8 \mathrm{~S}$ estrogen-binding protein in rat testes. Steroids, 32:165-177.

CARLSEN, E.; FIWERCMAN, A.; KEIDING, N. \& SKAKKEBAEK, N. E., 1992. Evidence for decreasing quality of semen during past 50 years. $B M J$, 305:609-613.

CERHAN, J. R.; CANTOR, K. P.; WILLIAMSON, K.; LYNCH, C. F.; TORNER, J. C. \& BURMEISTER, L. F., 1998. Cancer mortality among Iowa farmers: Recent results, time trends, and lifestyle factors. Cancer Causes \& Control, 9:311-319.

CHAPIN, R. E. \& GULATI, D. K., 1997. Pesticide/Fertilizer mix II (California). Environmental Health Perspectives, 105(Sup. 1):373.

CHECKOWAY, H.; DiFERDINANDO, G.; HULKA, B. S. \& MICKEY, D. D., 1987. Medical, life-style, and occupational risk factors for prostate cancer. Prostate, 10:79-88.

CHEN, C. W.; HURD, C.; VOROJEIKINA, D. P.; ARNOLD, S. F. \& NOTIDES, A. C., 1997. Transcriptional activation of the human estrogen receptor by DDT isomers and metabolites in yeast and MCF-7 cells. Biochemical Pharmacology, 53:1161-1172.

COCCO, P., 1997. Environmental exposure to p,p'DDE and human fertility. Bulletin of Environmental Contamination and Toxicology, 59:677-680.

COCCO, P. \& BENICHOU, J., 1998. Mortality from cancer of the male reproductive tract and Environmental exposure to $\mathrm{p}, \mathrm{p}^{\prime}$-dichloro-diphenyldichloroethylene (p,p'-DDE) in the United States. Oncology, 55:334-339.

COCCO, P.; FIGGS, L.; DOSEMECI, M.; HAYES, R.; LINET, M. S. \& HSING, A. W., 1998. Case-control study of occupational exposures and male breast cancer. Journal of Occupational and Environmental Medicine, 55:599-604.

CUMMINGS, A. M., 1997. Methoxychlor as a model for environmental estrogens. Critical Reviews in Toxicology, 27:367-379.

CURTIS, K. M.; SAVITZ, D. A.; WEINBERG, C. R. \& ARBUCKLE, T. E., 1999. The effect of pesticide exposure on time to pregnancy. Epidemiology, 10:112117.

DALY, M. \& OBRAMS, G. I., 1998. Epidemiology and risk assessment for ovarian cancer. Seminars in Oncology, 25:255-264.

DANZO, B. J., 1997. Environmental xenobiotics may disrupt normal endocrine function by interfering with the binding of physiological ligands to steroid receptors and binding proteins. Environmental Health Perspectives, 105:294-301.

DE COCK, J.; WESTVEER, K.; HEEDERIK, D.; te VELDE, E. \& VAN KOOIJ, R., 1994. Time to pregnancy and occupational exposure to pesticides in fruit growers in The Netherlands. Journal of Occupational and Environmental Medicine, 51:693699.

DEES, C.; ASKARI, M.; FOSTER, J. S.; AHAMED, S. \& WIMALASENA, J., 1997. DDT mimicks estradiol stimulation of breast cancer cells to enter the cell cycle. Molecular Carcinogenesis, 18:107-114.

DEMERS, A.; AYOTTE, P.; BRISSON, J.; DODIN, S.; ROBERT, J. \& DEWAILLY, E., 2000. Risk and aggressiveness of breast cancer in relation to plasma organochlorine concentrations. Cancer Epidemiology, Biomarkes \& Prevention, 9:161-166.

DEWAILLY, E.; DODIN, S.; VERREAULT, R.; AYOTTE, P.; SAUVÉ, L.; MORIN, J. \& BRISSON, J., 1994. High organochlorine body burden in women with estrogen receptor-positive breast cancer. Journal of the National Cancer Institute, 86:232-234.

DICH, J. \& WIKLUND, K., 1998. Prostate cancer in pesticide applicators in Swedish agriculture. Prostate, 34:100-112.

DICH, J.; WIKLUND, K. \& HOLM, L.-E., 1996. Testicular cancer in pesticide applicators in Swedish agriculture. Scandinavian Journal of Work, Environment \& Health, 22:66.

DONNA, A.; CROSIGNANI, P.; ROBUTTI, F.; BETTA, P. G.; BOCCA, R.; MARIANI, N.; FERRARIO, F; FISSI, R. \& BERRINO, F., 1989. Triazine herbicides and ovarian epithelial neoplasms. Scandinavian Journal of Work, Environment \& Health, 15:47-53.

DONNA, A.; BETTA, P. G.; ROBUTTI, F.; CROSIGNANI, P.; BERRINO, F. \& BELLINGERI, D., 1984. Ovarian mesothelial tumors and herbicides: A case-control study. Carcinogenesis, 5:941-942.

DORGAN, J. F.; BROCK, J. W.; ROTHMAN, N.; NEEDHAM, L. L.; MILLER, R.; STEPHENSON Jr., H. E.; SCHUSSLER, N. \& TAYLOR, P. R., 1999. Serum organochlorine pesticides and PCBs and breast cancer risk. Cancer Causes \& Control, 10:1-11.

ECKOLS, K.; WILLIAMS, J. \& UPHOUSE, L., 1989. Effects of chlordecone on progesterone receptors in immature and adult rats. Toxicology and $A p$ plied Pharmacology, 100:506-516.

EKBOM, A.; WICKLUND-GLYNN, A. \& ADAMI, H. O., 1996. DDT and testicular cancer. Lancet, 347:553554.

EPA (Environmental Protection Agency), 2000a. Chemical Fact Sheets. 4 August $2000<$ http:/ /www.epa. gov/oppefed $1 />$.

EPA (Environmental Protection Agency), 2000b. Federal Register Environmental Document - Pesticides. 10 October $2000<\mathrm{http} / /$ www.epa.gov/fedrgstr/EPA-PEST/>.

EXTOXNET (EXTENSION TOXICOLOGY NETWORK), 1996. Pesticide Information Profiles (PIPs). December $2000<\mathrm{http}$ ://ace.ace.orst.edu/info/etoxnet/ pips/ghindex.html $>$.

FALCK Jr., F.; RICCI Jr., A.; WOLFF, M. S.; GODBOLD, J. \& DECKERS, P., 1992. Pesticides and polychlorinated biphenyl residues in human breast lipids and their relation to breast cancer. Archives of En- 
vironmental Health, 47:143-146.

FENT, K., 1997. Endocrinally Active Substances in the Environment. State of the Art. July $2000<\mathrm{http}$ // www.epa.gov/endocrine/Project.html $>$.

FLEMING, L. E.; BEAN, J. A.; RUDOLPH, M. \& HAMILTON, K., 1999a. Mortality in a cohort of licensed pesticide applicators in Florida. Journal of Occupational and Environmental Medicine, 56:14-21.

FLEMING, L. E.; BEAN, J. A.; RUDOLPH, M. \& HAMILTON, K., 1999b. Cancer incidence in a cohort of licensed pesticide applicators in Florida. Journal of Occupational and Environmental Medicine, 41:279-288.

FOWLER, K. A.; GILL, K.; KIRMA, N.; DILLEHAY, D. L. \& TEKMAL, R. R., 2000. Overexpression of aromatase leads to development of testicular Leydig cell tumors: An in vivo model for hormone-mediated Testicular Cancer. American Journal of Pathology, 156:347-353.

GARCIA-RODRIGUEZ, J.; GARCIA-MARTIN, M.; NOGUERAS-OCARIA, M.; LUNA-DEL-CASTILLO, J.; GARCIA, M. E.; OLEA, N. \& LARDELLI-CLARET, P., 1996. Exposure to pesticides and cryptorchidism: Geographical evidence of a possible association. Environmental Health Perspectives, 104:1090-1095.

GHOSH, P.; BHATTACHARYA, S. \& BHATTACHARYA, S., 1989. Impact of nonlethal levels of Metacid-50 and carbaryl on thyroid function and cholinergic system of Channa punctatus. Biomedical and Environmental Sciences, 2:92-97.

GUTTES, S.; FAILING, K.; NEUMANN, K.; KLEINSTEIN, J.; GEORGII, S. \& BRUNN, H., 1998. Chlororganic pesticides and polychlorinated biphenyls in breast tissue of women with benign and malignant breast disease. Archives of Environmental Contamination and Toxicology, 35: 140-147.

HAYES, H. M.; TARONE, R. E.; CASEY, H. W. \& HUXSOLL, D. L., 1990. Excess of seminomas observed in Vietnam service U.S. military working dogs. Journal of the National Cancer Institute, 82:10421046.

HEINDEL, J. J.; GEORGE, J. D.; FAIL, P. A. \& GRIZZLE, T. B., 1997. Pesticide/Fertilizer mix III (Iowa). Environmental Health Perspectives, 105(Sup. 1):375.

HEISKEL, H.; SEIDLER, A.; BICKEBOLLER, R. \& ELSNER, G., 1998. Arbeitsbezogene Risikofaktoren des Prostatakarzinoms: Ergebnisse einer FallKontroll-Studie. Sozial - und Praventivmedizin, 43:282-292.

HENDERSON, B. E.; BERNSTEIN, L. \& ROSS, R., 1997. Etiology of cancer: Hormonal factors. In: Cancer. Principles and Practice of Oncology (V. T. DeVita Jr., S. Hellman \& S. A. Rosenberg, ed.), pp. 219$230,5^{\text {th }}$ Ed. Philadelphia: Lippincott-Raven Publishers.

HELZLSOUER, K. J.; ALBERG, A. J.; HUANG, H. Y.; HOFFMAN, S. C.; STRICKLAND, P. T.; BROCK, J. W.; BURSE, V. W.; NEEDHAM, L. L.; BELL, D. A.; LAVIGNE, J. A.; YAGER, J. D. \& COMSTOCK, G. W., 1999. Serum concentrations of organochlorine compounds and the subsequent development of breast cancer. Cancer Epidemiology, Biomarkes \& Prevention, 8:525-532.
HOYER, A. P.; GRANDJEAN, P.; JORGENSEN, T.; BROCK, J. W. \& HARTVIG, H. B., 1998. Organochlorine exposure and risk of breast cancer. Lancet, 352:1816-1820.

HOYER, A. P.; JORGENSEN, T.; BROCK, J. W. \& GRANDJEAN, P. J., 2000a. Organochlorine exposure and breast cancer survival. Journal of Clinical Epidemiology, 53:323-330.

HOYER, A. P.; JORGENSEN, T.; GRANDJEAN, P. \& HARTVIG, H. B., 2000b. Repeated measurements of organochlorine exposure and breast cancer risk (Denmark).Cancer Causes \& Control, 11:177184

HUNTER, D. J.; HANKINSON, S. E.; LADEN, F.; COLDITZ, G. A.; MANSON, J. E.; WILLETT, W. C.; SPEIZER, F. E. \& WOLFF, M. S., 1997. Plasma organochlorine levels and the risk of breast cancer. New England Journal of Medicine, 337:12531258.

HURLEY, P. M., 1998. Mode of carcinogenic action of pesticides inducing follicular cell tumors in rodents. Environmental Health Perspectives, 106: 437-445.

IARC (International Agency for Research on Cancer), 1991. DDT and associated compounds. In: Occupational Exposures in Insecticide Application, and some Pesticides. IARC Monographs for the Evaluation of Carcinogenic Risk of Chemicals to Humans, v. 53, pp. 179-249. Lyon: IARC.

IRVINE, D. S., 1994. Falling sperm quality. BMJ, 309: 476.

JOFFE, M., 1997. Time to pregnancy: A measure of reproductive function in either sex. Occupational and Environmental Medicine, 54:289-295.

JUBERG, D. R. \& LOCH-CARUSO, R., 1992. Investigation of the role of estrogenic action and prostaglandin E2 in DDT-stimulated rat uterine contractions ex vivo. Toxicology, 74:161-172.

KELCE, W. R.; STONE, C. R.; LAWS, S. C.; EARL-GRAY, L.; KEMPPAINEN, J. A. \& WILSON, E. M., 1995. Persistent DDT metabolite p,p'-DDE is a potent androgen receptor antagonist. Nature, 375:581585 .

KELLER-BYRNE, J. E.; KHUDER, S. A. \& SCHAUB, E. A., 1997. Meta-analyses of prostate cancer and farming. American Journal of Industrial Medicine, 31:580-586.

KETTLES, M. K.; BROWNING, S. R.; PRINCE, T. S. \& HORSTMAN, S. W., 1997. Triazine herbicide exposure and breast cancer incidence: An ecologic study of Kentucky counties. Environmental Health Perspectives, 105:1222-1227.

KHARRAZI, M.; POTASHNIK, G. \& GOLDSMITH, J. R., 1980. Reproductive effects of dibromochloropropane. Israel Journal of Medical Sciences, 10: 403-406.

KLOTZ, D. M.; ARNOLD, S. F. \& McLACHLAN, J. A., 1997a. Inhibition of $17 \beta$-estradiol and progesterone activity in human breast and endometrial cancer cells by carbamate insecticides. Life Sciences, 60:1467-1475.

KLOTZ, D. M.; LADLIE, B. L.; VONIER, P. M.; McLACHLAN, J. A. \& ARNOLD, S. F., 1997b. O,p'-DDT and its metabolites inhibit progesterone-dependent responses in yeast and human cells. Molecular and Cellular Endocrinology, 129:63-71. 
KOCIC, B.; JANKOVIC, S.; PETROVIC, B. \& TIODOROVIC, B., 1996. Neki nedovoljno ispitini faktori rizika za nastanak raka dojke (Some insufficiently recognized risk factors for breast cancer). Srpski Arhiv za Celokupno Lekarstvo, 124:175-178.

KRIEGER, N.; WOLFF, M. S.; HIATT, R. A.; RIVERA, M.; VOGELMAN, J. \& ORENTREICH, N., 1994. Breast cancer and serum organochlorines: A prospective study among white, black, and Asian women. Journal of the National Cancer Institute, 86:589-599.

KRISTENSEN, P.; ANDERSEN, A.; IRGENS, L. M.; BYE, A. S. \& VAGSTAD, N., 1996. Testicular cancer and parental use of fertilizers in agriculture. Cancer Epidemiology, Biomarkes \& Prevention, 5:3-9.

KRSTEV, S.; BARIS, D.; STEWART, P.; DOSEMECI, M.; SWANSON, G. M.; GREENBERG, R. S.; SCHOENBERG, J. B.; SCHWARTZ, A. G.; LIFF, J. M. \& HAYES, R. B., 1998. Occupational risk factors and prostate cancer in U.S. blacks and whites. American Journal of Industrial Medicine, 34:421-430.

KUPFER, D. \& BULGER, W. H., 1977. Interaction of o,p'-DDT with the estrogen-binding protein (EBP) in human mammary and uterine tumors. Research Communications in Molecular Pathology and Pharmacology, 16:451-462.

KUZ'MINSKAYA, U. A. \& IVANITSKII, V. A., 1979. Study of some biological indices of the state of the sympathoadrenaline system under the effect of polychlorocamphene. Environmental Health Perspectives, 30:91-95.

LARSEN, S. B.; GIWERCMAN, A.; SPANÒ, M. \& BONDE, J. P. E., FOR THE ASCLEPIOS WORKING GROUP, 1999. Seminal characteristics following exposure to pesticides among agricultural workers. Scandinavian Journal of Work, Environment \& Health, 25(Sup. 1):74-75.

LEBEL, G.; DODIN, S.; AYOTTE, P.; MARCOUX, S.; FERRON, L. A. \& DEWAILLY, E., 1998. Organochlorine exposure and the risk of endometriosis. Fertility and Sterility, 69:221-228.

LI, H.-C.; DEHAL, S. S. \& KUPFER, D., 1995. Induction of the heraptic CYP2B and CYP3A enzymes by the proestrogenic pesticide methoxychlor and by DDT in the rat. Effects on methoxychlor metabolism. Journal of Biochemical Toxicology, 10:51-61.

LILJEGREN, G.; HARDELL, L.; LINDSTROM, G.; DAHL, P. \& MAGNUSON, A., 1998. Case-control study on breast cancer and adipose tissue concentrations of congener specific polychlorinated biphenyls, DDE and hexachlorobenzene. European Journal of Cancer Prevention, 7:135-140.

LIU, P. S.; KAO, L. S. \& LIN, M. K., 1994. Organophosphates inhibit catecholamine secretion and calcium influx in bovine adrenal chromaffin cells. Toxicology, 90:81-91.

LOPEZ-CARRILLO, L.; BLAIR, A.; LOPEZ-CERVANTES, M.; CEBRIAN, M.; RUEDA, C.; REYES, R.; MOHAR, A. \& Bravo, J., 1997. Dichlorodiphenyltrichloroethane serum levels and breast cancer risk: A case-control study from Mexico. Cancer Research, 57:3728-3732.

MASON, R. R. \& SCHULTE, G. J., 1980. Estrogen-like effects of o,p'-DDT on the progesterone receptor of rat uterine cytosol. Research Communications in Molecular Pathology and Pharmacology, 29: 281-290.
MATTIOLI, F; ROBBIANO, L.; FAZZUOLI, L. \& BARACCHINI, P., 1994. Studies on the mechanism of the carcinogenic activity of amitrole. Fundamental and Applied Toxicology, 23:101-106.

McBLAIN, W. A., 1987. The levo enantiomer of o,p'DDT inhibits the binding of $17 \mathrm{~b}$-estradiol to the estrogen receptor. Life Sciences, 40:215-221.

McBLAIN, W. A. \& LEWIN, V., 1976. Differing estrogenic activities for the enantiomers of o, p'-DDT in immature female rats. Canadian Journal of Physiology and Pharmacology, 54:629-632.

MENDONCA, G. A.; ELUF NETO, J.; ANDRADA-SERPA, M. J.; CARMO, P. A.; BARRETO, H. H.; INOMATA, O. N. \& KUSSUMI, T. A., 1999. Organochlorines and breast cancer: A case-control study in Brazil. International Journal of Cancer, 83:596600.

MILLS, P. K., 1998. Correlation analysis of pesticide use data and cancer incidence rates in California counties. Archives of Environmental Health, 53: 410-413.

MOHAMMED, A.; HALLBERG, E.; RYDSTROM, J. \& SLANINA, P., 1985. Toxaphene: Accumulation in the adrenal cortex and effect on ACTH-stimulated corticosteroid synthesis in the rat. Toxicology Letters, 24:137-143.

MONOSSON, E.; KELCE, W. R.; LAMBRIGHT, C.; OSTBY, J. \& GRAY Jr., L. E., 1999. Peripubertal exposure to the antiandrogenic fungicide, vinclozolin, delays puberty, inhibits the development of androgen-dependent tissues, and alters androgen receptor function in the male rat. Toxicology and Industrial Health, 15:65-79.

MORGAN, D. P., 1989. Pesticide Poisoning Handbook. July $2000<$ http://hsis.fedworld.gov/PPH/>.

MORGENSTERN, H., 1982. Uses of ecological analysis in epidemiologic research. American Journal of Public Health, 72:1336-1343.

MORRISON, H.; SAVITZ, D.; SEMENCIW, R.; HULKA, B.; MAO, Y.; MORISON, D. \& WIGLE, D., 1993. Farming and prostate cancer mortality. American Journal of Epidemiology, 137:270-280.

MOYSICH, K. B.; AMBROSONE, C. B.; VENA, J. E.; SHIELDS, P. G.; MENDOLA, P.; KOSTYNIAK, P.; GREIZERSTEIN, H.; GRAHAM, S.; MARSHALL, J. R.; SCHISTERMAN, E. F. \& FREUDENHEIM, J. L., 1998. Environmental organochlorine exposure and postmenopausal breast cancer risk. Cancer Epidemiology, Biomarkes \& Prevention, 7:181-188.

MURAKAMI, M.; HOSOKAWA, S.; YAMADA, T.; HARAKAWA, M.; ITO, M.; KOYAMA, Y.; KIMURA, J.; YOSHITAKE, A. \& YAMADA, H., 1995. Speciesspecific mechanism in rat Leydig cell tumorigenesis by procymidone. Toxicology and Applied Pharmacology, 131:244-252.

MUSSALO-RAUHAMAA, H.; HASANEN, E.; PYYSALO, H.; ANTERVO, K.; KAUPPILA, R. \& PANTZAR, P., 1990. Occurrence of beta-hexachlorocyclohexane in breast cancer patients. Cancer, 66:2124-2128.

NESS, R. B.; GRISSO, J. A.; COTTREAU, C.; KLAPPER, J.; VERGONA, R.; WHEELER, J. E.; MORGAN, M. \& SCHLESSELMAN, J. J., 2000. Factors related to inflammation of the ovarian epithelium and risk of ovarian cancer. Epidemiology, 11:111-117.

OLAYA-CONTRERAS, P.; RODRIGUEZ-VILLAMIL, J.; POSSO-VALENCIA, H. J. \& CORTEZ, J. E., 1998. 
Organochlorine exposure and breast cancer risk in Colombian women. Cadernos de Saúde Pública, 14(Sup. 3):125-132.

OLSEN, J., 1994. Is human fecundity declining - And does occupational exposures play a role in such a decline if it exists? Scandinavian Journal of Work, Environment \& Health, 20:72-77.

PERLOE, M., 2000. Endometriosis. January 2001 <http://www.ivf.com/endomp.html>.

PESATORI, C.; ZOCCHETTI, C.; GUERCILENA, S.; CONSONNI, D.; TURRINI, D. \& BERTAZZI, P. A., 1994. Dioxin exposure and non-malignant health effects: A mortality study. Occupational and Environmental Medicine, 55:126-131.

PETRALIA, S. A.; CHOW, W. H.; McLAUGHLIN, J.; JIN, F.; GAO, Y. T. \& DOSEMECI, M., 1998. Occupational risk factors for breast cancer among women in Shanghai. American Journal of Industrial Medicine, 34:477-483.

PETRELLI, G.; FIGA-TALAMANCA, I.; TROPEANO, R.; TANGUCCI, M.; CINI, C.; AQUILANI, S.; GASPERINI, L. \& MELI, P., 2000a. Reproductive malemediated risk: Spontaneous abortion among wives of pesticide applicators. European Journal of Epidemiology, 16:391-393.

PETRELLI, G.; MUSTI, M. \& FIGA-TALAMANCA, I., 2000b. Esposizione a pesticidi in serra e fertilità maschile. Giornale Italiano di Medina del Lavoro et Ergonomia, 22:291-295.

POLLAN, M. \& GUSTAVSSON, P., 1999. High-risk occupations for breast cancer in the Swedish female working population. American Journal of Public Health, 89:875-881.

POTASHNIK, G. \& PORATH, A., 1995. Dibromochloropropane (DBCP): A 17-year reassessment of testicular function and reproductive performance. Journal of Occupational and Environmental Medicine, 37:1287-1292.

POTTERN, L. M.; MORRIS-BROWN, L. \& DEVESA, S. S., 1997. Epidemiology and pathogenesis of testicular cancer. In: Urologic Cancer (M. C. Ernstoff, J. A. Heaney \& R. E. Peschel, ed.), pp. 498-506, Cambridge: Blackwood Science.

RATCLIFFE, J. M.; SCHRADER, S. M.; STEENLAND, K.; CLAPP, D. E.; TURNER, T. \& HORNUNG, R. W., 1987. Semen quality in papaya workers ethylene dibromide. British Journal of Industrial Medicine, 44:317-326.

RATTNER, B. A.; SILEO, L. \& SCANES, C. G., 1982. Oviposition and the plasma concentrations of $\mathrm{LH}$, progesterone and corticosterone in bobwhite quail (Colinus virginianus) fed parathion. Journal of Reproduction and Fertility, 66:147-155.

REUBER, M. D., 1979. Interstitial cell carcinomas of the testis in Balb/C male mice ingesting methoxychlor. Journal of Cancer Research and Clinical Oncology, 93:173-179.

REUBER, M. D., 1980. Carcinogenicity and toxicity of methoxychlor. Environmental Health Perspectives, 36:205-219.

RIMAN, T.; PERSSON, I. \& NILSSON, S., 1998. Hormonal aspects of epithelial ovarian cancer: Review of epidemiological evidence. Clinical Endocrinology, 49:695-707.

ROBISON, A. K.; MUKKU, V. R.; SPALDING, D. M. \& STANCEL, G. M., 1984. The estrogenic activity of
DDT: The in vitro induction of an estrogen-inducible protein by o,p'-DDT. Toxicology and Applied Pharmacology, 76:537-543.

ROBISON, A. K.; SCHMIDT, W. A. \& STANCEL, G. M., 1985. Estrogenic activity of DDT: Estrogen-receptor profiles and the responses of individual uterine cell types following o,p'-DDT administration. Journal of Toxicology and Environmental Health, 16:493-508.

ROJAS, M.; BUSTOS-OBREGON, E.; MARTINEZ-GARCIA, F.; CONTRERAS, H. \& REGADERA, J., 1998. The effect of parathion on mouse testicular and epididymal development cultured in chicken allantochorion. Advances in Experimental Medicine and Biology, 444:201-206.

ROMIEU, I.; HERNANDEZ-AVILA, M.; LAZCANOPONCE, E.; WEBER, J. P. \& DEWAILLY, E., 2000. Breast cancer, lactation history, and serum organochlorines. American Journal of Epidemiol ogy, 152:363-370.

SAFE, S. H., 2000. Endocrine disruptors and human health - Is there a problem? Environmental Health Perspectives, 108:487-493.

SAFE, S.; ASTROFF, B.; HARRIS, M.; ZACHAREWSKI, T.; DICKERSON, R.; ROMKES, M. \& BIEGEL, L., 1991. Tetrachloro dibenzo-p-dioxin (TCDD) and related compounds as anti-estrogens: Characterization and mechanism of action. Pharmacology \& Toxicology, 69:400-409.

SCHRADER, T. J. \& COOKE, G. M., 2000. Examination of selected food additives and organochlorine food contaminants for androgenic activity in vitro. Toxicological Sciences, 53:278-288.

SCHECTER, A.; TONIOLO, P.; DAI, L. C.; THUY, L. T. \& WOLFF, M. S., 1997. Blood levels of DDT and breast cancer risk among women living in the north of Vietnam. Archives of Environmental Contamination and Toxicology, 33:453-456.

SEIBERT, H., 1997. Estrogenic Chemicals in the Environment: A New Problem? Endocrine Disruptor Research Initiative Federal Research Project Inventory. 3 February $1997<$ http//www.epa.gov/ endocrine/Project.html $>$.

SHARPE, R. M., 1995. Another DDT connection. $\mathrm{Na}$ ture, 375:538-539.

SHEN, K. \& NOVAK, R. F., 1997. DDT stimulates cerbB2, c-met, and STATS tyrosine phosphorylation, Grb2-Sos association, MAPK phosphorylation, and proliferation of human breast epithelial cells. Biochemical and Biophysical Research Communications, 231:17-21.

SIERRA-SANTOYO, A.; HERNANDEZ, M.; ALBORES, A. \& CEBRIAN, M. E., 2000. Sex-dependent regulation of hepatic cytochrome P-450 by DDT. Toxicological Sciences, 54:81-87.

SINGH, H. \& SINGH, T. P., 1981. Effect of parathion and aldrin on survival, ovarian 32P-uptake and gonadotrophic potency in a freshwater catfish, heteropneustes fossilis (Bloch). Endokrinologie, 77:173-178.

SISKIND, V.; GREEN, A.; BAIN, C. \& PURDIE, D., 1997. Breastfeeding, menopause, and epithelial ovarian cancer. Epidemiology, 8:188-191.

SKAKKEBAEK, N. E.; RAJPERT-De MEYTS, E.; JORGENSEN, N.; CARLSEN, E.; PETERSEN, P. M.; GIWERCMAN, A.; ANDERSEN, A. G.; JENSEN, T. K.; 
ANDERSSON, A. M. \& MULLER, J., 1998. Germ cell cancer and disorders of spermatogenesis: An environmental connection? Acta Pathologica, Microbiologica, et Immunologica Scandinavica, 106:3-11.

SMITH, E. M.; HAMMONDS-EHLERS, M.; CLARK, M. K.; KIRCHNER, H. L. \& FUORTES, L., 1997. Occupational exposures and risk of female infertility. Journal of Occupational and Environmental Medicine, 39:138-147.

SOTO, A. M.; CHUNG, K. L. \& SONNENSCHEIN, C., 1994. The pesticides endosulfan, toxaphene, and dieldrin have estrogenic effects on human estrogen-sensitive cells. Environmental Health Perspectives, 102:380-383.

SOTO, A. M.; SONNENSCHEIN, C.; CHUNG, K. L.; FERNANDEZ, M. F.; OLEA, N. \& SERRANO, F. O., 1995. The E-screen assay as a tool to identify estrogens: An update on estrogenic environmental pollutants. Environmental Health Perspectives, 103(Sup. 7):113-122.

STEINMETZ, R.; YOUNG, P. C.; CAPERELL-GRANT, A.; GIZE, E. A.; MADHUKAR, B. V.; BEN-JONATHAN, N. \& BIGSBY, R. M., 1996. Novel estrogenic action of the pesticide residue b-hexachlorocyclohexane in human breast cancer cells. Cancer Research, 56:5403-5409.

STELZER, A. \& CHAN, H. M., 1999. The relative estrogenic activity of technical toxaphene mixture and two individual congeners. Toxicology, 138:69-80.

STROHMER, H.; BOLDIZSAR, A.; PLOCKINGER, B.; FELDNER-BUSZTIN, M. \& FEICHTINGER, W., 1993. Agricultural work and male infertility. American Journal of Industrial Medicine, 24:587592.

STURGEON, S. R.; BROCK, J. W.; POTISCHMAN, N.; NEEDHAM, L. L.; ROTHMAN, N.; BRINTON, L. A. \& HOOVER, R. N., 1998. Serum concentrations of organochlorine compounds and endometrial cancer risk (United States). Cancer Causes \& Control, 9:417-424.

SUOMINEN, J. \& VIERULA, M., 1993. Semen quality of Finnish men. BMJ, 306:1579.

TAKAYAMA, S.; SIEBER, S. M.; DALGARD, D. W., THORGEIRSSON, U. P. \& ADAMSON, R. H., 1999. Effects of long-term oral administration of DDT on non human primates. Journal of Cancer Research and Clinical Oncology, 125:219-225.

THONNEAU, P.; LARSEN, S. B.; ABELL, A.; CLAVERT, A.; BONDE, J. P. E.; DUCOT, B. \& MULTIGNER, L., 1999a. Time to pregnancy and paternal exposure to pesticides in preliminary results from Danish and French studies. Scandinavian Journal of Work, Environment \& Health, 25(Sup. 1):62-63.

THONNEAU, P.; ABELL, A.; LARSEN, S. B.; BONDE, J. P.; JOFFE, M.; CLAVERT, A.; DUCOT, B.; MULTIGNER, L. \& DANSCHER, G., 1999b. Effects of pesticide exposure on time to pregnancy: Results of a multicenter study in France and Denmark. American Journal of Epidemiology, 150:157-163.

TIEMANN, U.; SCHNEIDER, F. \& TUCHSCHERER, A., 1996. Effects of organochlorine pesticides on DNA synthesis of cultured oviductal and uterine cells and on estrogen receptor of uterine tissue from heifers. Archives of Toxicology, 70:490-496.

TOMCZAK, S.; BAUMANN, K. \& LEHNERT, G., 1981.
Occupational exposure to hexachlorocyclohexane. IV. Sex hormone alterations in $\mathrm{HCH}$-exposed workers. International Archives of Occupational and Environmental Health, 48:81-87.

TOMENSON, J. A.; TAVES, D. R.; COCKETT, A. T. K.; McCUSKER, J.; BARRAJ, L.; FRANCIS, M.; PASTOOR, T. P.; WICKRAMARATNE, G. A. \& NORTHROP, H. L., 1999. An assessment of fertility in male workers exposed to molinate. Journal of Occupational and Environmental Medicine, 41:771-787.

TOPPARI, J.; LARSEN, J. C.; CHRISTIANSEN, P.; GIWERCMAN, A.; GRANDJEAN, P.; GUILLETTE, L. J.; JÉGOU, B.; JENSEN, T. K.; JOUANNET, P.; KEIDING, N.; LEFFERS, H.; McLACHLAN, J. A.; MEYER, O.; MULLER, J.; RAJPERT-De MEYTS, E.; SCHEIKE, T.; SHARPER, R.; SUMPTER, J. \& SKAKKEBAEK, N. E., 1995. Male Reproductive Health and Environmental Chemicals with Estrogenic Effects. Copenhagen: Danish Environmental Protection Agency, Ministry of the Environment and Energy.

TRAINA, M. E.; ADE, P.; SIEPI, G.; URBANI, E. \& PETRELLI, M. G., 1994. A review of the effect of pesticide formulations on male fertility. International Journal of Environmental Health Research, 4:38-47.

ULRICH, E. M.; CAPERELL-GRANT, A.; JUNG, S.-H.; HITES, R. A. \& BIGSBY, R. M., 2000. Environmentally relevant xenoestrogen tissue concentrations correlated to biological responses in mice. Environmental Health Perspectives, 108:973-977.

UNGER, M.; KIAER, H.; BLICHERT-TOFT, M.; OLSEN, J. \& CLAUSEN, J., 1984. Organochlorine compounds in human breast fat from deceased with and without breast cancer and in a biopsy material from newly diagnosed patients undergoing breast surgery. Environmental Research, 34:24-28.

VAN DER GULDEN, J. W.; KOLK, J. J. \& VERBEEK, A. L., 1995. Work environment and prostate cancer risk. Prostate, 27:250-257.

VAN DER GULDEN, J. W. \& VOGELZANG, P. F., 1996. Farmers at risk for prostate cancer. British Journal of Urology, 77:6-14.

VAN'T VEER, P.; LOBBEZOO, I. E.; MARTIN-MORENO, J. M.; GUALLAR, E.; GOMEZ-ARACENA, J.; KARDINAAL, A. F.; KOHLMEIER, L.; MARTIN, B. C.; STRAIN, J. J.; THAMM, M.; VAN ZOONEN, P.; BAUMANN, B. A.; HUTTUNEN, J. K. \& KOK, F. J., 1997. DDT (dicophane) and postmenopausal breast cancer in Europe: Case-control study. $B M J$, 315:81-85.

VAN WAELEGHEM, K.; DE CLERCQ, K.; VERMEULEN, L.; SCHOONJANS, L. \& COMHAIRE, F., 1994. Deterioration of sperm quality in young Belgian men during recent decades. Human Reproduction, 9(Sup. 4):73.

VOM SAAL, F. S.; NAGEL, S. C.; PALANZA, P.; BOECHLER, M.; PARMIGIANI, S. \& WELSHONS, W. V., 1995. Estrogenic pesticides: binding relative to estradiol in MCF-7 cells and effects of exposure during fetal life on subsequent territorial behaviour in male mice. Toxicology Letters, 77:343-350.

VONIER, P. M.; CRAIN, D. A.; McLACHLAN, J. A.; GUILLETTE Jr., L. J. \& ARNOLD, S. F., 1996. Interaction of environmental chemicals with estrogen 
and progesterone receptors from the oviduct of the American alligator. Environmental Health Perspectives, 104:1328-1322.

WARITZ, R. S.; STEINBERG, M.; KINOSHITA, F. K.; KELLY, C. M. \& RICHTER W. R., 1996. Thyroid function and thyroid tumors in toxaphene-treated rats. Regulatory Toxicology and Pharmacology, 24:184-192.

WASSERMANN, M.; NOGUEIRA, D. P.; TOMATIS, L.; MIRRA, A. P.; SHIBATA, H.; ARIE, G.; CUCOS, S. \& WASSERMANN, D., 1976. Organochlorine compounds in neoplastic and adjacent apparently normal breast tissue. Bulletin of Environmental Contamination and Toxicology, 15:478-484.

WEIDERPASS, E.; ADAMI, H. O.; BARON, J. A.; WICKLUND-GLYNN, A.; AUNE, M.; ATUMA, S. \& PERSSON, I., 2000. Organochlorines and endometrial cancer risk. Cancer Epidemiology, Biomarkers \& Prevention, 9:487-493.

WEIR, H. K.; MARRETT, L. D.; KREIGER, N.; DARLINGTON, G. A. \& SUGAR, L., 2000. Pre-natal and peri-natal exposures and risk of testicular germcell cancer. International Journal of Cancer, 87: 438-443.

WHORTON, M. D., 1994. Male occupational reproductive hazards. In: Occupational Medicine (C. Zenz, O. B. Dickerson \& E. P. Horvath Jr., ed.), pp. 870-874, 3rd Ed. Saint Louis: Mosby-Year Book.

WHORTON, D.; MILLBY, T. H.; KRAUSS, R. M. \& STUBBS, H. A., 1979. Testicular function in DBCP exposed pesticide workers. Journal of Occupational Medicine, 21:161-166.

WIKLUND, K.; DICH, J. \& HOLM, L.-E., 1986. Testicular cancer among agricultural workers and licensed pesticide applicators in Sweden. Scandinavian Journal of Work, Environment \& Health, 12:630-631.

WILKINSON, P.; THAKRAR, B.; SHADDICK, G.; STEVENSON, S.; PATTENDEN, S.; LANDON, M.; GRUNDY, C. \& ELLIOTT, P., 1997. Cancer incidence and mortality around the Pan Britannica Industries pesticide factory, Waltham Abbey. Occupational and Environmental Medicine, 54:101107.

WOLF, C. J.; LeBLANC, G. A.; OSTBY, J. S. \& GRAY Jr., L. E., 2000. Characterization of the period of sensitivity of fetal male sexual development to vinclozolin. Toxicological Sciences, 55:152-161.

WOLFF, M. S.; BERKOWITZ, G. S.; BROWER, S.; SENIE, R.; BLEIWEISS, I. J.; TARTTER, P.; PACE, B.; ROY, N.; WALLENSTEIN, S. \& WESTON, A., 2000a. Organochlorine exposures and breast cancer risk in New York city women. Environmental Research, 84:151-161.
WOLFF, M. S.; TONIOLO, P. G.; LEE, E. W.; RIVERA, M. \& DUBIN, N., 1993. Blood levels of organochlorine residues and risk of breast cancer. Journal of the National Cancer Institute, 85:648-652.

WOLFF, M. S.; ZELENIUCH-JACQUOTTE, A.; DUBIN, N. \& TONIOLO, P., 2000b. Risk of breast cancer and organochlorine exposure. Cancer Epidemiology, Biomarkes \& Prevention, 9:271-277.

YEN, S. S. C., 1991. The human menstrual cycle: Neuroendocrine regulstion. In: Reproductive Endocrinology. Physiology, Pathophisiology, and Clinical Management (S. S. C. Yen \& R. B. Jaffe, ed.), pp. 273-308, Philadelphia: Saunders \& Co.

ZHENG, T.; HOLFORD, T. R.; MAYNE, S. T.; TESSARI, J.; OWENS, P. H.; ZAHM, S. H.; ZHANG, B.; DUBROW, R.; WARD, B.; CARTER, D. \& BOYLE, P., 1999a. Environmental exposure to hexachlorobenzene (HCB) and risk of female breast cancer in Connecticut. Cancer Epidemiology, Biomarkes \& Prevention, 8:407-411.

ZHENG, T.; HOLFORD, T. R.; MAYNE, S. T.; TESSARI, J.; WARD, B.; CARTER, D.; OWENS, P. H.; BOYLE, P.; DUBROW, R.; ARCHIBEQUE-ENGLE, S.; DAWOOD, O. \& ZAHM, S. H., 2000. Risk of female breast cancer associated with serum polychlorinated biphenyls and 1,1-dichloro-2,2'-bis(pchlorophenyl)ethylene. Cancer Epidemiology, Biomarkes \& Prevention, 9:167-174.

ZHENG, T.; HOLFORD, T. R.; MAYNE, S. T.; WARD, B.; CARTER, D.; OWENS, P. H.; DUBROW, R.; ZAHM, S. H.; BOYLE, P.; ARCHIBEQUE, S. \& TESSARI, J., 1999b. DDE and DDT in breast adipose tissue and risk of female breast cancer. American Journal of Epidemiology, 150:453-458.

ZHOU, L. X.; DEHAL, S. S.; KUPFER, D.; MORRELL, S.; McKENZIE, B. A.; ECCLESTON Jr., E. D. \& HOLTZMAN, J. L., 1995. Cytochrome P450 catalyzed covalent binding of methoxychlor to rat hepatic, microsomal iodothyronine 5'-monodeiodinase, type I: Does exposure to methoxychlor disrupt thyroid hormone metabolism? Archives of Biochemistry and Biophysics, 322:390-394.

ZOBER, A.; HOFFMANN, G.; OTT, M. G.; WILL, W.; GERMANN, C. \& VAN RAVENZWAAY, B., 1995. Study of morbidity of personnel with potential exposure to vinclozolin. Occupational and Environmental Medicine, 5:233-241.

Submitted on 6 January 2001

Final version resubmitted on 7 May 2001

Approved on 1 June 2001 